\title{
Vitamin D as an Adjunctive Therapy in Asthma. Part 2: A Review of Human Studies
}

\author{
Conor Kerley \\ Technological University Dublin, conor.kerley@gmail.com \\ Basil Elnazir \\ National Children's Hospital, Dublin \\ John Faul \\ Connolly Hospital, Blanchardstown, Dublin.
}

See next page for additional authors

Follow this and additional works at: https://arrow.tudublin.ie/scschbioart

Part of the Medical Immunology Commons

\section{Recommended Citation}

Kerley CP, Elnazir B, Faul J, Cormican L. (2015) Vitamin D as an Adjunctive Therapy in Asthma. Part 2: A Review of Human Studies. Pulmonary Pharmacology and Therapeutics 2015 Jun; 32:75-92. doi: 10.1016/ j.pupt.2015.02.010.

This Article is brought to you for free and open access by the School of Biological Sciences at ARROW@TU Dublin. It has been accepted for inclusion in Articles by an authorized administrator of ARROW@TU Dublin. For more information, please contact arrow.admin@tudublin.ie, aisling.coyne@tudublin.ie,gerard.connolly@tudublin.ie.

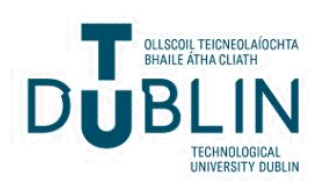


Authors

Conor Kerley, Basil Elnazir, John Faul, and Liam Cormican

This article is available at ARROW@TU Dublin: https://arrow.tudublin.ie/scschbioart/173 




This article appeared in a journal published by Elsevier. The attached copy is furnished to the author for internal non-commercial research and education use, including for instruction at the authors institution and sharing with colleagues.

Other uses, including reproduction and distribution, or selling or licensing copies, or posting to personal, institutional or third party websites are prohibited.

In most cases authors are permitted to post their version of the article (e.g. in Word or Tex form) to their personal website or institutional repository. Authors requiring further information regarding Elsevier's archiving and manuscript policies are encouraged to visit:

http://www.elsevier.com/authorsrights 


\title{
Vitamin D as an adjunctive therapy in asthma. Part 2: A review of human studies
}

 \\ a Respiratory and Sleep Diagnostics Department, Connolly Hospital, Blanchardstown, Dublin 15, Ireland \\ ${ }^{\mathrm{b}}$ School of Medicine and Medical Sciences, University College Dublin, Belfield, Dublin 4, Ireland \\ ${ }^{\mathrm{c}}$ Department of Paediatric Respiratory Medicine, The National Children's Hospital Dublin 24, Ireland
}

\section{A R T I C L E I N F O}

\section{Article history:}

Available online 5 March 2015

\section{Keywords:}

Vitamin D

Asthma

Allergy

Airway

Sun

Epidemiology

Diet

Nutrition

\begin{abstract}
A B S T R A C T
Vitamin D deficiency (VDD) is highly prevalent worldwide, with adverse effects on bone health but also potentially other unfavorable consequences. VDD and asthma-incidence/severity share many common risk factors, including winter season, industrialization, poor diet, obesity, dark skin pigmentation, and high latitude. Multiple anatomical areas relevant to asthma contain both the enzyme responsible for producing activated vitamin $\mathrm{D}$ and the vitamin $\mathrm{D}$ receptor suggesting that activated vitamin $\mathrm{D}(1,25-$ dihydroxyvitamin D) may have important local effects at these sites.

Emerging evidence suggests that VDD is associated with increased airway hyperresponsiveness, decreased pulmonary function, worse asthma control, and possibly decreased response to standard antiasthma therapy. However the effect is inconsistent with preliminary evidence from different studies suggesting vitamin $\mathrm{D}$ is both beneficial and detrimental to asthma genesis and severity.

Current evidence suggests that supplementation with moderate doses of vitamin D may be appropriate for maintenance of bone health in asthmatics, particularly steroid users. However emerging data from an increasing number of randomized, controlled, intervention studies of vitamin D supplementation in pediatric and adult asthma are becoming available and should help determine the importance, if any of vitamin $\mathrm{D}$ for asthma pathogenesis.

The purpose of this second of a two-part review is to review the current human literature on vitamin D and asthma, discussing the possible consequences of VDD for asthma and the potential for vitamin D repletion as adjunct therapy.
\end{abstract}

๑) 2015 Elsevier Ltd. All rights reserved.

\section{Introduction}

Much human research on vitamin D and asthmatic disease is now available. This second part of a two-part review will briefly introduce vitamin D and its sources. However, the main focus will be human evidence linking vitamin $D$ to human asthma, including epidemiological, case-control, cross-sectional, prospective and intervention studies. We will discuss the merits and limitations of each study design regarding asthma and vitamin D. However, unanswered questions remain. We have reviewed mechanisms by which vitamin D may influence asthmatic disease in part one of this

\footnotetext{
* Corresponding author. Respiratory and Sleep Diagnostics Department, Connolly Hospital, Blanchardstown, Dublin 15, Ireland. Tel.: +353 831458796.

E-mail addresses: conorkerley@gmail.com (C.P. Kerley), basil.elnazir@amnch.ie (B. Elnazir), doctorfaul@gmail.com (J. Faul), liamcormican@rcsi.ie (L. Cormican).
}

two-part review [92]. Therefore, we will conclude this review with some recommendations for future research in the area.

There are two major forms of fat-soluble vitamin D: vitamin $\mathrm{D}_{2}$ (ergocalciferol) available from plant sources such as ultraviolet-B (UV-B) irradiated mushrooms and vitamin $\mathrm{D}_{3}$ (cholecalciferol) available from animal sources such as oily fish and produced in human skin upon exposure to ultraviolet B radiation (UV-B). Although both forms of vitamin $\mathrm{D}$ are bioactive and available as a dietary supplement, it is recognized that vitamin $D_{3}$ is more potent [159].

Systemic vitamin D status is reliably indicated by the serum level of 25-hydroxyvitamin D (25(OH)D) [70,75,78], which reflects cutaneous photosynthesis and oral intake from both diet and supplements. Currently, there is no consensus on optimal levels of 25(OH)D. The 2010 Institute of Medicines (IOM) recommended that vitamin D deficiency (VDD) be defined as a 25(OH)D level $<50 \mathrm{nmol} / \mathrm{L}$, with a level $>50 \mathrm{nmol} / \mathrm{L}$ representing vitamin $\mathrm{D}$ 


\begin{tabular}{|c|c|}
\hline Abbreviations list & $\begin{array}{l}\text { International Study of Asthma and Allergies in } \\
\text { Childhood }\end{array}$ \\
\hline \multirow{3}{*}{$\begin{array}{l}\% \text { predicated } \mathrm{FEV}_{1} \text { percent predicated based on normative } \\
\text { values for healthy age and BMI matched } \\
\text { subjects. }\end{array}$} & international unit \\
\hline & long-acting $\beta$-agonist \\
\hline & the protein precursor to hCAP-18 which undergoes \\
\hline 1,25D 1,25-dihydroxyvitamin D & extracellular cleavage to generate a 37-residue active \\
\hline 25(OH)D 25-hydroxyvitamin D & cationic peptide \\
\hline AAR allergic rhinitis + allergic asthma & NHANES National Health and Nutrition examination survey \\
\hline asthma control questionnaire & oral corticosteroid \\
\hline asthma control test & OGG-1 8-Oxoguanine-DNA glycosylase; \\
\hline atopic dermatitis & odds ratio \\
\hline allergic rhinitis & $\mathrm{PC}_{20}-\mathrm{FEV}_{1}$ provocation dose of methacholine require to induce a \\
\hline airway smooth muscle & $20 \%$ drop in $\mathrm{FEV}_{1}$ \\
\hline asthma therapy assessment questionnaire & peak expiratory flow rate \\
\hline bronchoalveolar lavage fluid & randomized controlled trial \\
\hline body mass index & reactive oxygen species \\
\hline day & respiratory tract infection \\
\hline double-blind & retinoid $\mathrm{X}$ receptor- $\alpha$ \\
\hline DBRCT double-blind, randomized, placebo controlled trial & subcutaneous immunotherapy \\
\hline ED emergency department & specific immunotherapy \\
\hline exhaled nitric oxide & superoxide dismutases - enzymes which catalyze the \\
\hline fraction of exhaled nitric oxide & dismutation of the superoxide radical \\
\hline forced expiratory volume in $1 \mathrm{~s}$ & steroid resistant \\
\hline forced inspiratory volume in $1 \mathrm{~s}$ & T-reg cells regulatory $\mathrm{T}$ cells \\
\hline forkhead box P3 & transforming growth factor \\
\hline forced vital capacity & t helper \\
\hline glucocorticoids & ultraviolet-B radiation \\
\hline global initiative for asthma & vitamin $\mathrm{D}$ binding protein \\
\hline hs-CRP high sensitivity $C$ reactive protein & vitamin D deficiency \\
\hline ICS inhaled corticosteroid & vitamin D insufficiency \\
\hline interferon gamma & vitamin D receptor \\
\hline immunoglobulin E & vitamin $\mathrm{D}$ response element \\
\hline interleukin & vitamin D sufficiency \\
\hline intramuscularly & vitamin D toxicity \\
\hline Institute of Medicines & \\
\hline
\end{tabular}

sufficiency (VDS) [139]. However, these guidelines have been criticized as being overly conservative by being based almost solely on studies of bone health $[69,167]$. Higher 25(OH)D levels (e.g. $>100 \mathrm{nmol} / \mathrm{L}$ ) have been suggested to be necessary for optimal immune function and respiratory outcomes [17,76,78,79,166].

For the purposes of this review we will use the most up to date recommendations from the Endocrine Society [76] - see Table 1. Despite advances about the importance of vitamin D, VDD is widespread worldwide with recent estimates suggesting 1 billion people are affected worldwide [74].

Although some foods contain vitamin D (mainly oily fish and fortified products), the major source for most humans is cutaneous photosynthesis under the influence of UV-B radiation from sunshine [74]. Therefore, VDD - like asthma - is more common in polluted, industrialized regions [115], at high latitude [87] and in winter season [49]. Similar to asthma, body size and adiposity [51 ], as well as darker skin pigmentation [38], exposure to cigarette smoke $[10,73,123,153]$, pollution $[9,89]$ and physical inactivity

Table 1

Definitions of vitamin D status based on serum 25(OH)D level [76].

\begin{tabular}{lll}
\hline Definition & Abbreviation & Serum 25(OH)D level \\
\hline Vitamin D deficiency & VDD & $50 \mathrm{nmol} / \mathrm{L}$ \\
Vitamin D insufficiency & VDI & $50-75 \mathrm{nmol} / \mathrm{L}$ \\
Vitamin D sufficiency & VDS & $75-250 \mathrm{nmol} / \mathrm{L}$ \\
Vitamin D toxicity & VDT & $>375 \mathrm{nmol} / \mathrm{L}$ \\
\hline
\end{tabular}

$[73,145,163]$ are associated with decreased vitamin D status. Other determinants of vitamin D status include clothing and sunblock use [116], inadequate diet and supplement usage as well as genetic variation [179].

It is notable that the environmental changes attributable to the increase in asthma incidence and severity also cause VDD. The recent emergence of widespread VDD appears related to sun avoidance and seems to parallel the increased incidence of multiple diseases, including asthma.

\section{Methods}

References were identified by searches of MEDLINE, CINAHL, EMBASE and online Cochrane databases through January 2015. Keywords used included vitamin D and asthma, wheezing, airway inflammation, airway smooth muscle, and respiratory infection. Only manuscripts published in English are included. Articles were chosen according to their relevance for this review and their bibliographies were also searched for further references.

\section{Results and discussion}

\subsection{Evidence linking vitamin $D$ to asthma}

There are two opposing theories regarding the effect of increasing $25(\mathrm{OH}) \mathrm{D}$ status in asthma. We will consider both 
theories and present existing cross sectional and interventional evidence.

\subsubsection{Is vitamin D detrimental in asthma?}

Wjst and Dold first hypothesized that the introduction of vitamin D fortified foods was related to the asthma and allergy epidemic, suggesting that if protective antigen-reactive Th1 memory cells fail to develop, the subsequent predominance of Th2 cells can trigger allergic reactions [180]. This initial hypothesis was based on the observation that the introduction of vitamin $D$ food fortification and specific vitamin $D$ supplementation strategies seems to mirror the emergence of an asthma epidemic [175-178]. However, there is little evidence that $25(\mathrm{OH}) \mathrm{D}$ levels increased during this period and it is likely that several factors may even decreased 25(OH)D levels, including increased indoor time (i.e. indoor occupations and recreation) and increased sunscreen use. However, some animal work has seemingly supported the view that vitamin D is detrimental in asthma. VDR knockout mice do not develop airway inflammation or experimental asthma [174]. The same group went on to demonstrate that VDR expression is mandatory for the induction of lung inflammation [173]. Together these animal reports suggest that vitamin D and the VDR are important regulators of lung inflammation.

This initial hypothesis and animal model evidence was supported by limited human evidence. The first human report of potentially increased risk of atopy with vitamin D supplementation came in 1993. Peanut oil used for the pharmacological preparation of vitamin $D$ to prevent peanut sensitization was associated with a markedly increased risk of allergen sensitization $(\mathrm{OR}=9.0$; $\mathrm{p}<0: 003$ ) compared to the supplement without allergen [44]. Later trials of supplementation with peanut oil or water with dissolved vitamin D alone or in combination with vitamin A demonstrated increased adverse allergic outcomes, including asthma $[45,97,98]$. The preparations used contained a combination of peanut oil as well as vitamins $A$ and $D$, and therefore it is difficult to speculate on the individual contribution of each component. These early reports are supported by several prospective studies suggesting that early vitamin D supplementation may increase the risk of allergic disease among healthy infants $[8,59,82,130,164]$ and that vitamin $D$ may have detrimental effects on childhood lung function [42] and atopic disease [71,181].

However, the effect of vitamin D on immune and inflammatory signals may outweigh any potential shifting of Th1-Th2 balance and the majority of existing mechanistic [92] as well as observational data suggest that vitamin $\mathrm{D}$ repletion may be therapeutic in asthma. In fact, some authors have suggested that VDD may be responsible for the increase in allergic diseases and asthma prevalence worldwide [171,107,106]. However, interventional data has proved inconsistent (see below).

\subsubsection{Epidemiologic data}

There is decreased opportunity for vitamin D skin photosynthesis at higher latitude [74]. Therefore if vitamin D is truly important in asthmatic disease we can expect higher asthma incidence at higher latitude. Indeed, several reports have suggested that latitude is positively correlated to asthma $[2,56,87,95]$ and allergy [80]. However, not all ecological studies demonstrate this effect, with some studies noting no interaction [81,114], and others still an increased risk at lower latitude [131,151,170,176,187]. It should be noted that geographical latitude can only ever serve as a proxy for vitamin D status. Many factors affect asthma prevalence and may also vary by region, including healthcare resources, local population, genetics and pollution. Additionally, many factors affect the prevalence of VDD and may also vary by region and latitude, including diet and supplement use, religious clothing and sun habits. Indeed, VDD has been reported to common in low latitude countries with abundant sunshine [124,52].

Ethnic groups with darker skin have higher prevalence and severity of asthma when compared to those with lighter skin pigmentation residing in similar locations $[57,62,65,119]$. Although, many factors could contribute to this observation (e.g. dietary habits, healthcare access), it is noteworthy that those with darker skin pigmentation have the same capacity but significantly decreased efficiency of cutaneous vitamin D photosynthesis upon exposure to UV-B [38]. Therefore, heavily pigmented individuals will typically have lower 25(OH)D status compared to lighter pigmented individuals residing at similar latitudes [68,72].

Nevertheless, a randomized trial of Norwegian children with atopic eczema demonstrated significant improvements after 4 weeks in a sunny climate [26]. Further, an observational study in 2007 of Spanish asthmatic children revealed that health related quality of life was highest in summer and lowest in autumn [60]. Indeed, sunny hours have been inversely associated with asthma prevalence [5]. Additionally, a subsequent longitudinal cohort study of 415 Australian children followed from birth to age 16, demonstrated that reported summer sun exposure was associated with reduced eczema and rhinitis but not inhalant allergen sensitization or asthma risk [90]. However, other studies note an increased risk of asthma and allergic disease with higher UV-B exposure [131]. These discrepancies can potentially be explained by recent trends in lifestyle e.g. sunscreen use and increased time spent indoors, which would decrease vitamin D photosynthesis. Considering that UV-B radiation is the major source of vitamin $D$ for most populations, these observations appear to support a role for vitamin D in asthma.

Epidemiologic data demonstrate a positive association between 25(OH)D level and pulmonary function in healthy children $[184,185]$, adults $[19,37,158]$, elderly males but not females [165], asthmatics [154], smokers [101] and those with COPD [86]. A detailed retrospective analysis from the UK demonstrated a linear association between 25(OH)D and lung function including both forced expiratory volume in $1 \mathrm{~s}\left(\mathrm{FEV}_{1}\right)$ and forced vital capacity (FVC), which was consistent through the seasons and not fully explained by infections, adiposity or other lifestyle or socioeconomic measures [16]. A 20 year, Danish, prospective study with 18,507 subjects demonstrated that lower plasma $25(\mathrm{OH}) \mathrm{D}$ levels were associated with both lower lung function and faster decline in lung function (both FVC \& $\mathrm{FEV}_{1}$ ) [1]. Additionally, a crosssectional analysis of 650 mainly black, smokers revealed that there was no relationship between $25(\mathrm{OH}) \mathrm{D}$ and cathelicidin levels, but that lung function decrements were associated with low cathelicidin and were greatest among individuals with lower $25(\mathrm{OH}) \mathrm{D}$ levels [99].

Supporting the idea that vitamin D is important in asthmatic and atopic disease, inverse associations between 25(OH)D and allergy $[58,83,148]$ as well as asthma $[107,58,88]$ have also been reported. However, other reports suggest that dietary vitamin D [127] and serum 25(OH)D concentrations [147] were not related to $\mathrm{FEV}_{1}$ and that risk for atopic disease, including allergic rhinitis [181] and eczema [71] was higher with increased 25(OH)D. Taken together, most but not all existing epidemiological reports suggest that 25(OH)D may be an important and modifiable variable in the maintenance of lung health.

\subsubsection{Case-control studies of vitamin D status and asthma}

25 case control studies totaling 2568 asthmatic cases and 4376 controls have examined vitamin D intake, status as well as correlations with respiratory/atopic parameters in asthma cases compared to controls (see Table 2).

The case-control study by Carraro et al. deserves attention. The authors conducted a comprehensive observational study 
Table 2

Case control studies of vitamin D status and asthma.

\begin{tabular}{|c|c|c|c|c|c|}
\hline Population & Age (years) & Location & Latitude & Main findings & Reference \\
\hline $\begin{array}{l}80 \text { adult asthmatics \& } 80 \text { age } \& \text { sex- } \\
\text { matched controls. }\end{array}$ & $18-50$ & $\begin{array}{l}\text { Aberdeen, Scotland } \\
\text { \& Norfolk England }\end{array}$ & $52-57^{\circ} \mathrm{N}$ & $\begin{array}{l}\text { No significant differences in energy- } \\
\text { adjusted vitamin D intake or } 25(\mathrm{OH}) \mathrm{D} \\
\text { between cases \& controls. All subjects were } \\
\text { VDD. }\end{array}$ & {$[48]$} \\
\hline $\begin{array}{l}85 \text { African-American, childhood } \\
\text { asthmatics \& } 21 \text { healthy controls. }\end{array}$ & $6-20$ & Washington DC, USA & $39^{\circ} \mathrm{N}$ & $\begin{array}{l}\text { VDD \& VDI significantly greater in cases } \\
\text { than controls. }\end{array}$ & [57] \\
\hline $\begin{array}{l}50 \text { childhood asthmatics \& } 50 \text { healthy } \\
\text { controls. }\end{array}$ & $6-18$ & Shiraz, Iran & $30^{\circ} \mathrm{N}$ & $\begin{array}{l}25(\mathrm{OH}) \mathrm{D} \text { was significantly lower in cases } \\
\text { than controls and positively correlated with } \\
\mathrm{FEV}_{1} \text { and } \mathrm{FEV}_{1} / \mathrm{FVC} \text {. No correlation with } \\
\text { eosinophil counts, asthma duration, } \\
\text { number of hospitalization or unscheduled } \\
\text { visits in the previous year. }\end{array}$ & [3] \\
\hline $\begin{array}{l}45 \text { asthmatic children \& } 59 \text { healthy } \\
\text { controls. }\end{array}$ & $9-11$ & Verona, Italy & $45^{\circ} \mathrm{N}$ & $\begin{array}{l}\text { No significant difference in } 25(\mathrm{OH}) \mathrm{D} \\
\text { between cases and controls. } 25(\mathrm{OH}) \mathrm{D} \\
\text { positively correlated with FVC and } \mathrm{FEV}_{1} \text { but } \\
\text { negatively with exercise induced } \\
\text { bronchoconstriction. }\end{array}$ & {$[35,36]$} \\
\hline $\begin{array}{l}483 \text { asthmatic children \& } 483 \text { age, } \\
\text { gender \& ethnicity matched controls. }\end{array}$ & $<15$ & Doha, Qatar & $25^{\circ} \mathrm{N}$ & $\begin{array}{l}25(\mathrm{OH}) \mathrm{D} \text { levels were significantly lower } \\
\text { and IgE significantly higher in cases than } \\
\text { controls with a negative correlation } \\
\text { evident. Cases had less exposure to } \\
\text { sunshine and lower exercise. VDD was the } \\
\text { strongest predictor of asthma in this } \\
\text { population. }\end{array}$ & [53] and [15] \\
\hline $\begin{array}{l}36 \text { children with SR asthma, } 26 \text { with } \\
\text { moderate asthma, and } 24 \text { healthy } \\
\text { controls. }\end{array}$ & $6-16$ & London, England & $52^{\circ} \mathrm{N}$ & $\begin{array}{l}\text { 25(OH)D levels were significantly lower in } \\
\text { SR asthma than either mild asthmatics or } \\
\text { controls and inversely correlated with ASM } \\
\text { mass, bronchodilator response and IgE but } \\
\text { positively correlated with asthma control, } \\
\text { FEV }_{1} \text { and FVC. Further low 25(OH)D was } \\
\text { correlated with asthma exacerbation and } \\
\text { medication usage. }\end{array}$ & [66] \\
\hline $\begin{array}{l}287 \text { asthmatic children \& } 273 \text { healthy } \\
\text { children. }\end{array}$ & $6-14$ & San Juan, Puerto Rico & $18^{\circ} \mathrm{N}$ & $\begin{array}{l}\text { No significant difference in } 25(\mathrm{OH}) \mathrm{D} \\
\text { between cases and controls. Lower } 25(\mathrm{OH}) \mathrm{D} \\
\text { correlated with severe asthma } \\
\text { exacerbation, atopy, and a lower } \mathrm{FEV}_{1} / \mathrm{FVC} \\
\text { in cases. }\end{array}$ & [22] \\
\hline $\begin{array}{l}103 \text { asthmatics \& } 102 \text { healthy control } \\
\text { subjects. }\end{array}$ & $8.5-46$ & Denver, Colorado & $39^{\circ} \mathrm{N}$ & $\begin{array}{l}\text { VDD was evident in } 47.6 \% \text { of patients and } \\
56.8 \% \text { of controls. In multivariate regression } \\
\text { models, } 25(\mathrm{OH}) \mathrm{D} \text { correlated positively with } \\
\text { expression of vitamin D regulated genes, } \\
\text { but was only significant in children. An } \\
\text { inverse correlation between } 25(\mathrm{OH}) \mathrm{D} \text { and } \\
\text { serum IgE levels was observed but only in } \\
\text { children. 25(OH)D was significantly } \\
\text { inversely correlated with ICS dose, again } \\
\text { only in children. }\end{array}$ & [63] \\
\hline $\begin{array}{l}15 \text { children with SR asthma, } 7 \text { with } \\
\text { moderate asthma, \& } 6 \text { non-asthmatic } \\
\text { controls. }\end{array}$ & $6-16$ & London, England & $52^{\circ} \mathrm{N}$ & 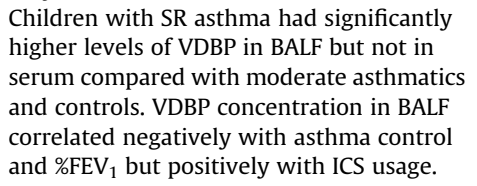 & [67] \\
\hline $\begin{array}{l}39 \text { children with controlled asthma and } \\
30 \text { age- and sex-matched controls. }\end{array}$ & $6-16$ & El Manar, Tunisia & $37^{\circ} \mathrm{N}$ & $\begin{array}{l}\text { VDD was higher in asthma compared to } \\
\text { control, VDS was lower in asthma than } \\
\text { control. Th1/Th2 ratio and CD25(+) } \\
\text { Foxp3(+) T-reg cells were positively related } \\
\text { to } 25(\mathrm{OH}) \text { D level while IL-17 was } \\
\text { negatively correlated. }\end{array}$ & [109] \\
\hline $\begin{array}{l}\text { Of } 25,616 \text { Norwegian adults who } \\
\text { participated in } 2 \text { health surveys } \\
1995-1997 \text { and } 2006-2008 \text {, a nested } \\
\text { case-control study included } 584 \\
\text { new-onset asthma cases and } 1958 \\
\text { non-asthma controls. }\end{array}$ & $19-55$ & $\begin{array}{l}\text { Nord-Trøndelag, } \\
\text { Norway }\end{array}$ & $63^{\circ} \mathrm{N}$ & $\begin{array}{l}\text { After adjustment for potential asthma risk } \\
\text { factors, baseline VDD was not significantly } \\
\text { correlated with asthma in either women or } \\
\text { men. Co-existent allergic rhinitis modified } \\
\text { the association in men only. }\end{array}$ & [110] \\
\hline $\begin{array}{l}263 \text { asthmatic children \& } 284 \text { healthy } \\
\text { controls. }\end{array}$ & $2-19$ & Worchester, USA & $42^{\circ} \mathrm{N}$ & $\begin{array}{l}\text { No significant difference in } 25(\mathrm{OH}) \mathrm{D} \\
\text { between cases and controls. } 25(\mathrm{OH}) \mathrm{D} \text { did } \\
\text { not relate to asthma severity. }\end{array}$ & {$[120]$} \\
\hline $\begin{array}{l}42 \text { non-severe asthmatic children, } 11 \\
\text { with severe asthma and } 15 \text { healthy, } \\
\text { non-asthmatic children. }\end{array}$ & $8-17$ & Padova, Italy & $45^{\circ} \mathrm{N}$ & $\begin{array}{l}\text { A metabolomic approach to exhaled breath } \\
\text { condensate (breathomics) revealed that the } \\
\text { absence of ercalcitriol, (active metabolite of } \\
\text { vitamin } \mathrm{D}_{2} \text { ) differentiated severe asthma } \\
\text { from both non-severe asthma and healthy } \\
\text { children. }\end{array}$ & [29] \\
\hline
\end{tabular}


Table 2 (continued)

\begin{tabular}{|c|c|c|c|c|c|}
\hline Population & Age (years) & Location & Latitude & Main findings & Reference \\
\hline $\begin{array}{l}30 \text { infants with recurrent wheezing and } \\
45 \text { healthy, similar aged infants } \\
\text { without any history of acute or } \\
\text { chronic illness }\end{array}$ & Infants & Ankara, Turkey & $40^{\circ} \mathrm{N}$ & $\begin{array}{l}25(\mathrm{OH}) \mathrm{D} \text { was not statistically different } \\
\text { between the groups. However, the sample } \\
\text { size was small, mean } 25(\mathrm{OH}) \mathrm{D} \text { was lower in } \\
\text { cases than controls and VDI was common } \\
\text { ( } 90 \% \text { of wheezers, } 77.8 \% \text { of controls). }\end{array}$ & [133] \\
\hline $\begin{array}{l}\text { Prospective cohort study of } 20 \\
\text { asthmatics and } 19 \text { non-asthmatics } \\
\text { followed for } \sim 1 \mathrm{y} \text {. }\end{array}$ & Not reported & Minnesota, USA & $44^{\circ} \mathrm{N}$ & $\begin{array}{l}\text { Overall negative correlation between } \\
25(\mathrm{OH}) \mathrm{D} \text { and decreased pneumococcal } \\
\text { antibody titers during follow-up, especially } \\
\text { significant among those with asthma and/or } \\
\text { atopy. }\end{array}$ & [141] \\
\hline $\begin{array}{l}85 \text { asthmatic children \& } 85 \text { non- } \\
\text { asthmatic children. }\end{array}$ & $2-14$ & $\begin{array}{l}\text { Tekirdag, } \\
\text { Turkey }\end{array}$ & $37^{\circ} \mathrm{N}$ & $\begin{array}{l}25(\mathrm{OH}) \mathrm{D} \text { was significantly lower in } \\
\text { asthmatic children. There was a negative } \\
\text { correlation between } 25(\mathrm{OH}) \mathrm{D} \text { and ER/ } \\
\text { hospital admissions, RTI incidence, asthma } \\
\text { attacks and asthma severity. }\end{array}$ & [162] \\
\hline $\begin{array}{l}50 \text { asthmatic children \& } 25 \text { non- } \\
\text { asthmatic children. }\end{array}$ & $1-15$ & Lucknow, India & $29^{\circ} \mathrm{N}$ & $\begin{array}{l}\text { VDI was correlated with asthma incidence } \\
\text { and decreased asthma control. }\end{array}$ & [7] \\
\hline $\begin{array}{l}35 \text { children with AAR, and } 11 \text { patients } \\
\text { with AR \& } 28 \text { healthy controls. }\end{array}$ & $8-13$ & Palermo, Italy & $39^{\circ} \mathrm{N}$ & $\begin{array}{l}25(\mathrm{OH}) \text { was highest in controls followed by } \\
\text { AR and then AAR, while plasma IL-31 and } \\
33 \text { were lowest in controls followed by AR } \\
\text { and AAR. Neither plasma IL-31 or IL-33 } \\
\text { correlated with 25(OH)D. 25(OH)D } \\
\text { correlated negatively with IgE levels and } \\
\text { total atopy index only in AAR. }\end{array}$ & [20] \\
\hline $\begin{array}{l}40 \text { wheezy infants; } 30 \text { age-and-gender } \\
\text { matched healthy infants. }\end{array}$ & $1-3$ & Samsun, Turkey & $41^{\circ} \mathrm{N}$ & $\begin{array}{l}25(\mathrm{OH}) \mathrm{D} \text { levels were lower in wheezy } \\
\text { infants vs. controls. There was a negative } \\
\text { relationship between } 25(\mathrm{OH}) \mathrm{D} \text { and IgE } \\
\text { levels. }\end{array}$ & [46] \\
\hline $\begin{array}{l}120 \text { asthamtic children and } 74 \text { age \& } \\
\text { gender matched, non asthmatic } \\
\text { controls. }\end{array}$ & $4.4 \pm 1.2$ & Istanbul, Turkey & $41^{\circ} \mathrm{N}$ & $\begin{array}{l}\text { Mean } 25(\mathrm{OH}) \mathrm{D} \text { level was slightly but not } \\
\text { significantly lower in cases than controls. } \\
\text { Among cases, the total number of } \\
\text { exacerbations, asthma severity and } \\
\text { systemic GCS need in the previous year } \\
\text { were significantly higher in the VDD group. }\end{array}$ & [50] \\
\hline $\begin{array}{l}69 \text { active asthamics (wheezing in the } \\
\text { past } 12 \text { months and ever asthma on } \\
\text { the ISAAC questionnaire) and } 671 \\
\text { controls (no hisotry of wheeinzg of } \\
\text { asthma). }\end{array}$ & $16-17$ & Cyprus & $35^{\circ} \mathrm{N}$ & $\begin{array}{l}\text { In adjusted models, mean } 25(\mathrm{OH}) \mathrm{D} \text { levels } \\
\text { were significantly lower amongst } \\
\text { asthamtics compared to controls. Within } \\
\text { asthmatics, there was a negative trend } \\
\text { between } 25(\mathrm{OH}) \mathrm{D} \text { and the number of } \\
\text { reported asthma severity indicators. }\end{array}$ & [93] \\
\hline 68 asthmatics and 77 healthy women. & $14-65$ & North Jordan & $32^{\circ} \mathrm{N}$ & $\begin{array}{l}\text { The prevalence of low } 25(\mathrm{OH}) \mathrm{D} \\
\text { (<37.5 nmol/L) was non statistically higher } \\
\text { in asthmatic women compared with } \\
\text { controls. Decreased } 25(\mathrm{OH}) \mathrm{D} \text { correlated } \\
\text { posisitvely with number of asthma } \\
\text { medications, whereas } 25(\mathrm{OH}) \mathrm{D} \text { directly } \\
\text { correlated with ACT and GINA classification. } \\
\text { After adjusting for age, the odds of having } \\
\text { VDD for asthmatic women were } 35.9 \text { times } \\
\text { higher than that for control women }\end{array}$ & [143] \\
\hline $\begin{array}{l}44 \text { asthmatic children and } 44 \text { healthy } \\
\text { controls. }\end{array}$ & $5-13$ & Bangalore, India & $32^{\circ} \mathrm{N}$ & $\begin{array}{l}\text { 25(OH)D levels were significnatly lower in } \\
\text { asthmatics vs. controls. 25(OH)D was } \\
\text { significantly positively correlated with \% } \\
\text { FEV }_{1} \text { and } \mathrm{FEV}_{1} / \mathrm{FVC}^{2} \text {. }\end{array}$ & [149] \\
\hline $\begin{array}{l}30 \text { children with acute wheeze and } 101 \\
\text { age-matched controls with no } \\
\text { history of wheeze or sensitization to } \\
\text { airborne allergens. }\end{array}$ & $0.5-4$ & Stockholm, Sweden & $62^{\circ} \mathrm{N}$ & $\begin{array}{l}\text { VDI was correlated with } 270 \% \text { increased risk } \\
\text { of acute wheeze. No correlation between } \\
25(\mathrm{OH}) \text { and atopy, presence of virus/ } \\
\text { bacteria or recurrent RTI. }\end{array}$ & [152] \\
\hline 73 wheezing children and 75 controls & Not reported & Istanbul, Turkey & $41^{\circ} \mathrm{N}$ & $\begin{array}{l}\text { No significant difference in } 25(\mathrm{OH}) \mathrm{D} \\
\text { between cases \& controls. However, } 25(\mathrm{OH}) \\
\text { D was significantly lower in recurrent } \\
\text { wheezers ( }>3 \text { wheezing attacks) \& children } \\
\text { with a positive Asthma Predictive Index. }\end{array}$ & [162] \\
\hline
\end{tabular}

Abbreviations: 25(OH)D = 25-hydroxyvitamin D; AAR = allergic rhinitis + allergic asthma; ACT = asthma control test; AR = allergic rhinitis; BALF = bronchoalveolar lavage fluid; $\mathrm{ER}=$ emergency room; $\mathrm{FEV}_{1}=$ forced expiratory volume in $1 \mathrm{~s} ; \mathrm{FVC}=$ forced vital capacity; GCS = glucocorticoids; GINA = global initiative for asthma; ICS = inhaled corticosteroid; IgE = immunoglobulin E; IL = interleukin; ISAAC = International Study of Asthma and Allergies in Childhood; RTI = respiratory tract infection; SR = steroid resistant; T-reg cells = regulatory T cells; VDBP = vitamin D binding protein; VDD = vitamin D deficiency; VDI $=$ vitamin D insufficiency; VDS = vitamin D sufficiency.

regarding the metabolomics of exhaled breath condensate (breathomics) in severe asthmatic children vs. non-severe asthmatic children and healthy children. They observed that the absence of ercalcitriol (an active metabolite of vitamin $\mathrm{D}_{2}$ ) differentiated severe asthma from both children with non-severe asthma and healthy children. This is perhaps the first report of vitamin $\mathrm{D}$ being recovered specifically in the lung. The authors speculate that children with severe asthma and treated with high-dose inhaled corticosteroids (ICS) may have insufficient vitamin D in the airways [29]. 
Observational studies, including case-control studies have several well-known limitations. Choice of controls can determine the observations and therefore even when efforts to match for confounding variables are made, the results can be biased. Further, even those with statistical adjustments, observational studies are limited by potential confounding. Therefore, it is impossible to ascertain whether an insufficient $25(\mathrm{OH}) \mathrm{D}$ level is responsible for reduced asthma control or that poor asthma control leads to decreased 25(OH)D status through acute inflammation as has been reported post-orthopedic surgery $[138,168]$ or reduced sun exposure due to asthma related inactivity. A recent in vivo study demonstrated that acute lung inflammation induced by exposure to house dust mite did not lead to altered 25(OH)D levels [33] suggesting that altered vitamin D status is not caused by allergic inflammation. However, children with wheezing, shortness of breath or allergy may avoid sunlight and outdoor activities $[14,15,162]$ and therefore present with lower 25(OH)D.

Existing case-control studies regarding vitamin D and asthma have compared asthmatics to healthy controls by assessing measurements which were collected simultaneously and only at a single time point. Therefore it is not possible to determine temporal relationships between exposure and outcome. Further, many of these study populations exhibit widespread VDD and VDI and therefore it is difficult to comment on the effect of higher 25(OH)D on asthma parameters.

Importantly, more than being interested in whether vitamin D intake and 25(OHOD status differs between asthmatic cases and non-asthmatic controls, the key question is whether vitamin $\mathrm{D}$ can influence asthma pathogenesis, severity and control. Because casecontrol studies can not answer these questions, these studies must be interpreted with caution. Hence, case-control studies are therefore placed low in the hierarchy of scientific evidence.

\subsubsection{Cross-sectional studies of vitamin D status in asthma}

Although, vitamin D may be of importance in adult asthma $[105,154]$, the association of vitamin D deficiency with severity of asthma is reported to be particularly strong in children [63] however this observation is not consistent [88]. Nevertheless, available cross-sectional data from 36 studies, involving 386,584 subjects suggest that low $25(\mathrm{OH}) \mathrm{D}$ is associated with poor control, increased exacerbation, reduced lung function and, increased medication usage in asthmatics (Table 3 ).

These cross-sectional studies suffer from many of the same limitations as case-control studies. In particular, assessments were conducted simultaneously and typically only at a single time point only. Further, the widespread nature of VDD and VDI prevents the assessment of high $25(\mathrm{OH}) \mathrm{D}$ on asthma parameters. Similar to case-control studies, the results of cross-sectional reports must be interpreted with caution. Ultimately, these observational studies provide associations between vitamin $\mathrm{D}$ and asthma but can not determine cause or effect and hence are only a step in understanding relationships between vitamin $\mathrm{D}$ and respiratory outcomes.

\subsubsection{Prospective studies of vitamin D status and asthma outcomes}

In contrast to case-control and cross-sectional studies, prospective studies follow subjects who are similar but differ with respect to certain factors. These factors can be studied to determine how they affect certain outcomes. There are 7 post-natal prospective studies regarding asthma, involving a total of 14,041 subjects followed for 1-31 years (Table 4).

Compared to observational studies, prospective cohort studies are superior regarding assessment of sequence between exposure and outcome. However, the longitudinal design of these studies means there is a lag between assessment of exposure and assessment of outcome. Because many factors influence both asthma pathogenesis and 25(OH)D levels and because 25(OH)D levels ae known to fluctuate over time, prospective studies too are limited in this context. Therefore interventional trials are best suited to study the effects of vitamin D and asthmatic disease.

\subsubsection{Interventional data of vitamin $D$ in asthma}

Case-control, cross-sectional and prospective studies designs are interesting and provide insights into any potential relationship between vitamin $\mathrm{D}$ and asthma outcomes. However, intervention data, particularly from randomized, controlled trials designed to specifically assess the impact of vitamin $D$ on asthma parameters provide far more robust information. There are 17 published trials of vitamin D supplementation in asthma involving 1578 asthmatics with varying doses and preparations of vitamin $\mathrm{D}$ followed for 4-52 weeks (Table 5).

The idea that vitamin $\mathrm{D}$ therapy could be therapeutic in asthma and allergic disease dates back to the early 20th century. Vitamin D was only discovered around this time. This led to a successful treatment of rickets and interest in other conditions, including asthma and allergy. Viosterol (which contained ergosterol, the precursor to ergocalciferol - vitamin $D_{2}$ ) was the vehicle of choice for these early investigations into asthma.

An early pilot study involving a heterogenous group of 11 subjects with either non-atopic asthma $(\mathrm{n}=3)$, chronic uriticaria $(\mathrm{n}=2)$ or ragweed allergy + asthma $(\mathrm{n}=6)$ treated with very large doses of viosterol (up to 1,380,000 IU bi-weekly for weeks to months) reported variable results in the Journal of the American Medical Association in 1933. In this pilot study, non-atopic asthmatics and subjects with uriticaria showed little improvement while subjects with ragweed allergy showed varying but obvious improvements [137].

These observations led the same investigators to conduct a subsequent larger study focusing on 212 patients specifically with asthmatic allergic to ragweed. The treatments were high dose viosterol $(120,000-300,000 \mathrm{IU} /$ day, $\mathrm{n}=68)$ or high dose viosterol and pollen injection $(n=144)$. In the viosterol only group, $82.4 \%$ experienced definite significant relief. In the viosterol + pollen group, $96.5 \%$ had comparable degrees of relief. The authors wrote that: ' $92 \%$ of the entire series were definitely and significantly relieved'. Interestingly, despite the massive doses of vitamin $\mathrm{D}_{2}$ utilized, hypercalcemia was not evident [136].

These early American studies were followed up by some publications in small European journals in the mid 20th century $[28,85]$. In 1976, a German group reported a double-blind, crossover trial of oral calcium + vitamin $\mathrm{D}_{2}$ (undescribed doses) on 12 patients with allergic bronchial asthma and airway obstruction. Within 60 min of application, a statistically significant reduction of airway resistance and intrathoracic gas volume, as well as an increase of $\mathrm{FEV}_{1}$ and forced inspiratory volume in $1 \mathrm{~s}\left(\mathrm{FIV}_{1}\right)$ was observed compared to placebo. It was concluded that calcium, given orally in combination with vitamin $\mathrm{D}_{2}$, causes a decrease of airway obstruction in patients with allergic bronchial asthma [161].

These early trials are limited by the large doses of vitamin D used, use of vitamin $D_{2}$ as opposed to vitamin $D_{3}$, sub-optimal trial design and missing details. Nevertheless and despite the inconsistent beneficial effects observed from these early trials, interest in the therapeutic potential of vitamin D in asthma seemed to decrease and the next asthma specific intervention trial, following multiple reports correlating vitamin D with worse asthma outcomes in human, animal and cell models, was not performed until 2009.

Before these vitamin D intervention trial, reports appeared suggesting an increased risk of atopy with peanut oil + vitamins A and $D$. The first report of potentially increased risk of atopy with 
Table 3

Cross sectional studies of vitamin D status and asthma.

\begin{tabular}{|c|c|c|c|c|c|}
\hline Population & Age (years) & Location & Latitude & Main findings & Reference \\
\hline 18,224 adults. & Not reported & USA wide & $28-48^{\circ} \mathrm{N}$ & $\begin{array}{l}\text { 25(OH)D was not correlated with allergic } \\
\text { sensitization. Risk of AR increased across } \\
\text { quartiles of } 25(\mathrm{OH}) \text { D. }\end{array}$ & {$[181]$} \\
\hline $\begin{array}{l}100 \text { subjects with low } 25(\mathrm{OH}) \mathrm{D} \\
(<25 \mathrm{nmol} / \mathrm{L})\end{array}$ & $10-73$ & Massachusetts, USA & $41^{\circ} \mathrm{N}$ & $\begin{array}{l}\text { The mean BMI was } 44.8 \mathrm{~kg} / \mathrm{m}^{2} 25(\mathrm{OH}) \mathrm{D} \text { was not } \\
\text { correlated with prevalence of asthma or AR. }\end{array}$ & [132] \\
\hline $\begin{array}{l}\text { \& } 190 \text { VDS subjects attending a weight } \\
\text { management centre. }\end{array}$ & & & & $\begin{array}{l}\text { Low } 25(\mathrm{OH}) \mathrm{D} \text { was correlated with increased AD } \\
\text { compared to VDS. }\end{array}$ & \\
\hline 616 asthmatic children. & $6-14$ & $\begin{array}{l}\text { Costa Rica } \\
\text { (city not specified) }\end{array}$ & $\sim 10^{\circ} \mathrm{N}$ & $\begin{array}{l}25(\mathrm{OH}) \mathrm{D} \text { levels were inversely correlated with } \\
\text { total IgE, eosinophil count and hospitalization } \\
\text { for asthma in the past year. }\end{array}$ & [23] \\
\hline 7288 adults. & 45 & UK wide & $51-58^{\circ} \mathrm{N}$ & $\begin{array}{l}\text { Non-linear correlation between 25(OH)D \& } \\
\text { serum IgE, where both low and high 25(OH)D } \\
\text { were correlated with elevated IgE. }\end{array}$ & {$[83]$} \\
\hline 1024 asthmatic children. & $7-11$ & USA wide & $28-48^{\circ} \mathrm{N}$ & $\begin{array}{l}\text { Lower } 25(\mathrm{OH}) \mathrm{D} \text { levels were correlated with } \\
\text { increased ED visits and hospitalizations for } \\
\text { asthma. }\end{array}$ & {$[24]$} \\
\hline 100 asthmatic children. & $4-10$ & Denver, USA & $40^{\circ} \mathrm{N}$ & $\begin{array}{l}\text { 25(OH)D levels were inversely correlated with } \\
\text { total IgE, number of positive aeroallergen skin } \\
\text { tests and steroid usage but positively correlated } \\
\text { with } \mathrm{FEV}_{1} \text { and } \mathrm{FEV}_{1} / \mathrm{FVC} \text {. }\end{array}$ & [146] \\
\hline 54 asthmatic adults. & $2-49$ & Denver, USA & $40^{\circ} \mathrm{N}$ & $\begin{array}{l}\text { 25(OH)D level was inversely correlated with } \\
\text { total IgE, number of positive aeroallegen skin } \\
\text { tests and use of steroids but positively } \\
\text { correlated with } \mathrm{FEV}_{1} \text { and } \mathrm{FEV}_{1} / \mathrm{FVC} \text {. }\end{array}$ & {$[154]$} \\
\hline 75 asthmatic children. & $5-11$ & Verona, Italy & $45^{\circ} \mathrm{N}$ & $\begin{array}{l}\text { 25(OH)D correlated positively with } \mathrm{FEV}_{1} \text {, FVC } \\
\text { and ACT score. }\end{array}$ & {$[35,36]$} \\
\hline $\begin{array}{l}\text { Prospective study of } 436 \text { children, with } \\
25(\mathrm{OH}) \mathrm{D} \text { measured at } 2 \mathrm{y} \text { and } \\
\text { supplement usage assessed at age } 1 \text {, } \\
2 \text { and } 6-7 \text { years. }\end{array}$ & $6-7$ & Maastricht, The Netherlands & $51^{\circ} \mathrm{N}$ & $\begin{array}{l}25(\mathrm{OH}) \mathrm{D} \text { levels and vitamin D supplement use } \\
\text { in childhood were not correlated with lung } \\
\text { function }\end{array}$ & {$[42]$} \\
\hline 483 asthmatic children. & $<15$ & Doha, State of Qatar & $25^{\circ} \mathrm{N}$ & $\begin{array}{l}\text { Lower } 25(\mathrm{OH}) \text { D was correlated with more } \\
\text { allergic disease and elevated serum IgE. }\end{array}$ & [53] \\
\hline 4979 adults. & $>20$ & USA wide & $28-48^{\circ} \mathrm{N}$ & $\begin{array}{l}25(\mathrm{OH}) \mathrm{D}<25 \mathrm{nmol} / \mathrm{L} \text { was positively correlated } \\
\text { with prevalence of allergies after adjusting for } \\
\text { age, gender, race, smoking, alcohol, and } \\
\text { educational status. }\end{array}$ & {$[58]$} \\
\hline 6857 adults \& children. & $>6$ & USA wide & $28-48^{\circ} \mathrm{N}$ & $\begin{array}{l}\text { 25(OH)D level was inversely correlated with } \\
\text { both current wheeze and asthma in adjusted } \\
\text { analysis. Among those with asthma, lower } \\
\text { 25(OH)D was correlated with increased odds of } \\
\text { both ED visits and exacerbation in the past year. }\end{array}$ & {$[88]$} \\
\hline $\begin{array}{l}21 \text { subjects with asthma and } 23 \\
\text { subjects with } A D \text {, or AR and atopic } \\
\text { sensitization. }\end{array}$ & Not reported & Minnesota, USA & $46^{\circ} \mathrm{N}$ & $\begin{array}{l}\text { Positive correlation between serum } 25(\mathrm{OH}) \mathrm{D} \\
\text { and positive pneumococcal antibody levels in } \\
\text { asthmatic subjects An inverse correlation was } \\
\text { observed in non-asthmatic patients. }\end{array}$ & [103] \\
\hline 435 adults. & $>18$ & Beijing, China & $39^{\circ} \mathrm{N}$ & $\begin{array}{l}89 \% \text { were VDD. After adjustment for } \\
\text { confounders, } 25(\mathrm{OH}) \mathrm{D} \text { was positively correlated } \\
\text { with } \mathrm{FEV}_{1}, \% \mathrm{FEV} \mathrm{F}_{1} \text {, and } \mathrm{FEV}_{1} / \mathrm{FVC} \text {. No correlation } \\
\text { between } 25(\mathrm{OH}) \mathrm{D} \text { and } \mathrm{IgE} \text {. }\end{array}$ & [105] \\
\hline $\begin{array}{l}3724 \text { year olds and } 3288 \text { year olds from } \\
\text { the Prevention and Incidence of } \\
\text { Asthma and Mite Allergy birth cohort } \\
\text { study. }\end{array}$ & 4 and 8 & Wageningen, Holland & $51^{\circ} \mathrm{N}$ & $\begin{array}{l}25(\mathrm{OH}) \mathrm{D} \text { level at age } 4 \text { was inversely with } \\
\text { asthma at age } 4-8 \text { but } 25(\mathrm{OH}) \mathrm{D} \text { level at age } 8 \\
\text { was positively correlation with asthma. }\end{array}$ & [164] \\
\hline 22 moderate/severe asthmatics. & $18-75$ & London, England & $52^{\circ} \mathrm{N}$ & $\begin{array}{l}\text { 25(OH)D levels correlated strongly with } \mathrm{CD} 4(+) \\
\text { Foxp3 }(+) \text { T-cell numbers. }\end{array}$ & {$[31]$} \\
\hline 16 atopic individuals ( 9 with asthma). & $18-44$ & Baltimore, USA & $39^{\circ} \mathrm{N}$ & $\begin{array}{l}25(\mathrm{OH}) \mathrm{D} \text { and } 1,25 \text { were low in the airways. } \\
\text { After allergen challenge, } 25(\mathrm{OH}) \mathrm{D}, 1,25 \mathrm{D} \& \mathrm{LL}- \\
37 \text { were increased in BALF compared to saline } \\
\text { and correlated with each other. The increase in } \\
25(\mathrm{OH}) \mathrm{D} \text { and } 1,25 \mathrm{D} \text { correlated with the } \\
\text { magnitude of inflammation and increases in LL- } \\
37 \text {. }\end{array}$ & [108] \\
\hline $\begin{array}{l}994 \text { participants (asthma prevalence } \\
\text { was } 5.4 \% \text { ) }\end{array}$ & $\geq 65$ & $\begin{array}{l}\text { South Korea } \\
\text { (city not specified) }\end{array}$ & $\sim 36^{\circ} \mathrm{N}$ & $\begin{array}{l}\text { With multivariate logistic regression, asthma } \\
\text { risk increased in proportion to an increased BMI } \\
\text { or abdominal subcutaneous adiposity. } \\
\text { However, no correlation was found with } \\
\text { visceral adiposity, serum adiponectin levels, or } \\
\text { 25(OH)D levels }\end{array}$ & {$[150]$} \\
\hline 1024 asthmatic children & $7-11$ & USA wide & $28-48^{\circ} \mathrm{N}$ & $\begin{array}{l}\text { VDD was correlated with decreased lung } \\
\text { function (prebronchodilator } \mathrm{FEV}_{1} \text { ) compared to } \\
\text { children with VDI or VDS. }\end{array}$ & [182] \\
\hline $\begin{array}{l}\text { Asthmatic out-patients (number of } \\
\text { subjects not specified) }\end{array}$ & Not reported & San Juan, Puerto Rico & $18^{\circ} \mathrm{N}$ & $\begin{array}{l}80 \% \text { were VDD. } 25(\mathrm{OH}) \mathrm{D} \text { correlated positively } \\
\text { with ACT score but negatively with PEFR. }\end{array}$ & [188] \\
\hline
\end{tabular}


Table 3 (continued)

\begin{tabular}{|c|c|c|c|c|c|}
\hline Population & Age (years) & Location & Latitude & Main findings & Reference \\
\hline $\begin{array}{l}121 \text { predominantly African-American } \\
\text { urban, preschool asthmatic children. }\end{array}$ & $2-6$ & Baltimore, USA & $38^{\circ} \mathrm{N}$ & $\begin{array}{l}23 \% \text { were VDD, } 31 \% \text { were VDI. There was a } \\
\text { modest, statistically significant inverse } \\
\text { correlation between } 25(\mathrm{OH}) \text { D levels and total } \\
\text { IgE. }\end{array}$ & {$[21]$} \\
\hline 15,212 individuals. & $>19$ & $\begin{array}{l}\text { South Korea } \\
\text { (city not specified) }\end{array}$ & $\sim 36^{\circ} \mathrm{N}$ & $\begin{array}{l}\text { After adjusting for potential confounders, } \\
25(\mathrm{OH}) \mathrm{D} \text { levels were significantly lower in } \mathrm{AD} \\
\text { than in those without this diagnosis. Compared } \\
\text { with VDI, VDD increased the odds of } \mathrm{AD} \text {. There } \\
\text { was no relationship between } 25(\mathrm{OH}) \mathrm{D} \text { and } \\
\text { asthma, allergic rhinitis, or IgE sensitization. }\end{array}$ & [34] \\
\hline $\begin{array}{l}\text { Secondary analyses of } 2 \text { cohorts: } 6,487 \\
\text { children from NHANES \& } 226 \\
\text { asthmatic children enrolled in study } \\
\text { of asthma control. }\end{array}$ & $12-20$ & USA wide & $28-48^{\circ} \mathrm{N}$ & $\begin{array}{l}25(\mathrm{OH}) \mathrm{D} \text { level showed either no relation or } \\
\text { minor contradictory correlations with asthma } \\
\text { severity, treatment requirements, spirometry } \\
\text { and atopy/inflammation. } 25(\mathrm{OH}) \mathrm{D} \text { did not differ } \\
\text { between asthmatics and non-asthmatics }\end{array}$ & [61] \\
\hline 1,115 children. & $9-10$ & Toyama, Japan & $37^{\circ} \mathrm{N}$ & $\begin{array}{l}60 \% \text { were VDI. After adjustment for } \\
\text { confounders, no relationship between } 25(\mathrm{OH}) \mathrm{D} \\
\text { and asthma, rhinoconjunctivitis, or eczema. }\end{array}$ & {$[84]$} \\
\hline 280 adult asthmatics. & $45.0 \pm 13.8$ & Mainz, Germany & $50^{\circ} \mathrm{N}$ & $\begin{array}{l}67 \% \text { were VDD. } 25(\mathrm{OH}) \mathrm{D} \text { levels were related to } \\
\text { asthma severity and control. The frequency of } \\
\text { VDI or VDD was significantly higher in patients } \\
\text { with severe or uncontrolled asthma and was } \\
\text { correlated with a lower } \mathrm{FEV}_{1} \text {, higher eNO and } \\
\text { higher BMI. }\end{array}$ & [94] \\
\hline 125 asthmatic children. & $6-18$ & Bangkok, Thailand & $13^{\circ} \mathrm{N}$ & $\begin{array}{l}\text { VDD was present in } 31,17 \text { and } 13 \% \text { of children } \\
\text { with uncontrolled, partly controlled and } \\
\text { controlled asthma. However, there was no } \\
\text { significant difference in pulmonary function, } \\
\text { asthma exacerbation, ICS dose, anti- } \\
\text { inflammatory drugs, or ED visit or } \\
\text { hospitalization between different vitamin D } \\
\text { statuses. }\end{array}$ & [96] \\
\hline 121 asthmatic adults. & $48 \pm 16$ & $\begin{array}{l}\text { Costa Rica } \\
\text { (city not specified) }\end{array}$ & $\sim 10^{\circ} \mathrm{N}$ & $\begin{array}{l}\text { VDI was correlated with a higher risk of severe } \\
\text { asthma. High } 25(\mathrm{OH}) \mathrm{D} \text { levels were inversely } \\
\text { correlated with risk of hospitalization or ED } \\
\text { visit during the last year. Although there } \\
\text { appeared to be a direct relationship between } \\
25(\mathrm{OH}) \mathrm{D} \text { and } \mathrm{FEV}_{1} \text {, it did not reach statistical } \\
\text { significance. No relationship between } 25(\mathrm{OH}) \mathrm{D} \\
\text { levels and some allergy markers. }\end{array}$ & [122] \\
\hline 2478 non-asthmatic, older adults. & $\geq 55$ & Singapore & $1^{\circ} \mathrm{N}$ & $\begin{array}{l}\text { Adjusted multiple regression models dietary } \\
\text { fish intake at least thrice weekly was correlated } \\
\text { with FEV } \text { F }_{1} \text { No significant as with vitamin D } \\
\text { supplements was observed. }\end{array}$ & [127] \\
\hline $\begin{array}{l}1833 \text { children (rates of asthma, allergic } \\
\text { rhinitis and wheezing were } 38.5 \% \text {, } \\
34.8 \% \text { and } 35.7 \% \text { ) }\end{array}$ & $<16$ & Doha, Qatar & $25^{\circ} \mathrm{N}$ & $\begin{array}{l}\text { VDD prevalence was significantly higher in } \\
\text { children with wheezing, AR, and asthma than in } \\
\text { healthy children. VDD was a significant } \\
\text { correlate for asthma, AR and wheezing. }\end{array}$ & {$[14]$} \\
\hline 1134 asthmatic children. & 14.8 & Lima and Tumbes, Peru & $3.6-12^{\circ} \mathrm{S}$ & $\begin{array}{l}\text { In stratified analyses of multivariable logistic } \\
\text { regression, the correlation between lower } \\
25(\mathrm{OH}) \mathrm{D} \text { and asthma was limited to children } \\
\text { with atopy. No correlations between } 25(\mathrm{OH}) \mathrm{D} \\
\text { and eNO, total serum IgE and pulmonary } \\
\text { function. }\end{array}$ & [32] \\
\hline $\begin{array}{l}308,000 \text { adults. } 6.9 \%(\mathrm{n}=21,237) \text {, had } \\
\text { physician diagnosed asthma. }\end{array}$ & $22-50$ & Tel Aviv, Israel & $32^{\circ} \mathrm{N}$ & $\begin{array}{l}\text { No correlation between } 25(\mathrm{OH}) \mathrm{D} \text { and asthma } \\
\text { incidence. VDD was correlated with a } 25 \% \\
\text { greater risk of asthma exacerbation compared } \\
\text { to VDS independent of BMI and smoking. }\end{array}$ & {$[40]$} \\
\hline $\begin{array}{l}32 \text { asthmatic patients during severe } \\
\text { exacerbation }\end{array}$ & $47.5 \pm 15$ & Sichuan, China & $30^{\circ} \mathrm{N}$ & $\begin{array}{l}\text { Compared to VDS, VDD was correlated with } \\
\text { lower FEV }{ }_{1} \text { and SOD, increased ROS release, } \\
\text { increased DNA damage, increased TNF- } \alpha \text {, OGG1 } \\
\text { and NFKB expression and NFאB } \\
\text { phosphorylation. }\end{array}$ & {$[100]$} \\
\hline 760 adults with self reported asthma & $19-55$ & Trondheim, Norway & $63^{\circ} \mathrm{N}$ & $\begin{array}{l}44 \% \text { were VDD but VDD was was not correlated } \\
\text { with airway obstruction except in asthmatic } \\
\text { men without allergic rhinitis. }\end{array}$ & [102] \\
\hline 1213 children. & $6-12$ & Canada wide & $50-70^{\circ} \mathrm{N}$ & $\begin{array}{l}\text { Children with either VDD \& VDS were more } \\
\text { likely to report current wheeze and ever asthma } \\
\text { in comparison to VDI. The rate of increase in \% } \\
\text { predicted } \mathrm{FEV}_{1} \& \text { FVC with age was greatest in } \\
\text { the VDI group. }\end{array}$ & [128] \\
\hline 92 adult asthmatics. & $24-85$ & New Mexico, USA & $31^{\circ} \mathrm{N}$ & $\begin{array}{l}\text { VDS was significantly correlated with decreased } \\
\text { total and severe asthma exacerbations, and ER } \\
\text { visits. }\end{array}$ & [142] \\
\hline 2815 children & 10 & Germany (4 separate cities) & $48-51^{\circ} \mathrm{N}$ & $\begin{array}{l}\text { There was no association between } 25(\mathrm{OH}) \mathrm{D} \text { and } \\
\text { either asthma or AR. }\end{array}$ & [169] \\
\hline
\end{tabular}


Table 3 (continued)

\begin{tabular}{lllll}
\hline Population & Age (years) & Location & Latitude & Main findings \\
\hline 1315 children. & $5-18$ & Taoyuan, Taiwan & $25^{\circ} \mathrm{N}$ & $\begin{array}{l}51 \% \text { and } 90.3 \% \text { were VDD and VDI. After } \\
\text { adjusting for potential confounders. Serum } \\
\end{array}$ \\
& & & $\begin{array}{l}\text { 25(OH)D was not correlated with asthma, } \\
\text { rhinitis, eczema, atopy, or total serum IgE. }\end{array}$ \\
\hline
\end{tabular}

Abbreviations: $25(\mathrm{OH}) \mathrm{D}=25$-hydroxyvitamin $\mathrm{D} ; \mathrm{ACT}=$ asthma control test; $\mathrm{AD}=$ atopic dermatitis; $\mathrm{AR}=$ allergic rhinitis; ASM = airway smooth muscle; $\mathrm{BALF}=$ bronchoalveolar lavage fluid; DBRCT = double-blind, randomized, controlled trial; $\mathrm{ED}=$ emergency department; $\mathrm{ED}=\mathrm{emergency}$ department; eNO = exhaled nitric oxide; $\mathrm{FEV}_{1}=$ forced expiratory volume in $1 \mathrm{~s} ; \mathrm{FVC}=$ forced vital capacity; ICS = inhaled corticosteroid; IgE = Immunoglobulin E; LL-37 = the C-terminal part cathelicidn; $\mathrm{OCS}=$ oral corticosteroid; OGG-1 = 8-Oxoguanine-DNA glycosylase; PEFR = peak expiratory flow rate; ROS = reactive oxygen species; SOD = superoxide dismutases; $\mathrm{SR}=$ steroid resistant; VDD = vitamin D deficiency; VDI = vitamin D insufficiency; VDS = vitamin D sufficiency.

vitamin D supplementation came in 1993. Peanut oil used for the pharmacological preparation of vitamin $\mathrm{D}$ to prevent peanut sensitization was associated with a markedly increased risk of sensitization to allergen ( $\mathrm{OR}=9.0 ; \mathrm{p}<0: 003)$ compared to the supplement without allergen [44]. Later trials of supplementation with vitamins $\mathrm{A}$ and $\mathrm{D}$ dissolved in peanut oil and particularly when dissolved in water demonstrated increased adverse allergic outcomes, including asthma $[45,97,98]$. The preparations used contained a combination of peanut oil as well as vitamins A and D, and therefore it is difficult to speculate on the individual contributions.

Since a call to action for vitamin D intervention trials in asthma in 2009 [47], several small trials have been published:

Majak et al. conducted a double-blind, randomized, placebocontrolled trial (DBRCT) to assess specific immunotherapy (SIT) in combination with ICS (prednisone $20 \mathrm{mg}$ daily) + either placebo or vitamin $\mathrm{D}_{3}$ (1000 IU/week). This was a one-year trial at high latitude $\left(51^{\circ} \mathrm{N}\right)$ and enrolled 54 asthmatic children allergic to house dust mites on SIT. Early administration of ICS prevented the benefits of SIT. However, the addition of low dose vitamin $\mathrm{D}_{3}$ (equivalent to 143 IU/day) preserved the benefits of SIT, despite concomitant ICS use. Indeed, all negative clinical- and immunological-effects of prednisone were prevented by administration of low dose vitamin $\mathrm{D}_{3}$ [111]. For more detail on the potential of vitamin $\mathrm{D}$ as an adjunct to anti-inflammatory therapy in asthma, see section 3.2.6 in partone of this review.

Urashima et al. conducted a DBRCT to assess the effectiveness of vitamin $\mathrm{D}_{3}(2000 \mathrm{IU} / \mathrm{d})$ vs. placebo in reducing influenza $\mathrm{A}$ incidence in 334 Japanese school children. This four-month study included physician diagnosed asthma exacerbations as a secondary outcome. Although an $83 \%$ reduction in asthma attacks with vitamin D was observed (RR: 0.17; 95\% CI: 0.04, 0.73; $\mathrm{p}=0.006$ ),

Table 4

Prospective studies of post-natal cohorts of vitamin D and asthma.

\begin{tabular}{|c|c|c|c|c|c|}
\hline Population & Age (years) & Location & Latitude & Main findings & Reference \\
\hline 5007 subjects born in 1966 assessed at age 31 . & 31 & Finland wide & $60-70^{\circ} \mathrm{N}$ & $\begin{array}{l}\text { Atopy, allergic rhinitis and asthma prevalence } \\
\text { at age } 31 \text { was higher in participants who had } \\
\text { received regular vitamin D supplementation } \\
\text { during the first year of life, even after adjusting } \\
\text { for multiple behavioral and social factors. }\end{array}$ & {$[82]$} \\
\hline $\begin{array}{l}123 \text { neonates followed for } 6 \mathrm{y} \text {. All children were } \\
\text { prescribed supplements containing } 1000 \mathrm{IU} \\
\text { vitamin } \mathrm{A} \text { and } 400 \mathrm{IU} \text { vitamin } \mathrm{D}_{3} \text { daily from } 6 \\
\text { weeks to } 24 \text { months of age. }\end{array}$ & Neonates & Umeå, Sweden & $64^{\circ} \mathrm{N}$ & $\begin{array}{l}\text { High self reported vitamin D intake during their } \\
\text { first } 10 \text { months was significantly positively } \\
\text { correlated with atopic dermatitis and non- } \\
\text { significantly correlated with allergic rhinitis and } \\
\text { atopic asthma compared to low self reported } \\
\text { vitamin D intake. }\end{array}$ & {$[8]$} \\
\hline $\begin{array}{l}\text { Longitudinal study of } 989 \text { subjects at age } 6 \text {; } \\
1380 \text { at age } 14 ; 689 \text { with data at both ages. }\end{array}$ & 6 and 14 & Perth, Australia & $32^{\circ} \mathrm{S}$ & $\begin{array}{l}25(\mathrm{OH}) \mathrm{D} \text { level was inversely correlated with } \\
\text { asthma and atopy at both age } 6 \text { and } 14.25(\mathrm{OH}) \\
\text { D level at age 6y was inversely correlated with } \\
\text { asthma, rhinoconjunctivitis and atopy } \\
\text { development at age } 14 \text {. }\end{array}$ & [77] \\
\hline $\begin{array}{l}\text { Prospective study of }>2259 \text { children ( } 4 \% \\
\text { wheezers, } 14 \% \text { asthma, } 8 \% \text { flexural dermatitis). } \\
\text { Mean follow up was } 5.7 \mathrm{y} \text {. }\end{array}$ & 9.8 and 15.5 & $\begin{array}{l}\text { Bristol, United } \\
\text { Kingdom }\end{array}$ & $51^{\circ} \mathrm{N}$ & $\begin{array}{l}25(\mathrm{OH}) \mathrm{D}_{2} \text { was inversely correlated with } \\
\text { flexural dermatitis and wheezing. } 25(\mathrm{OH}) \mathrm{D}_{3} \\
\text { was positively correlated with flexural } \\
\text { dermatitis and wheezing. } 25(\mathrm{OH}) \mathrm{D}_{2} \text { was weakly } \\
\text { positively correlated with } \mathrm{FEV}_{1} \text {, and FVC but } \\
25(\mathrm{OH}) \mathrm{D}_{3} \text { was not correlated with lung } \\
\text { function. }\end{array}$ & [157] \\
\hline $\begin{array}{l}\text { Post hoc analysis of an RCT comparing daily } \\
\text { low-dose budesonide to intermittent high- } \\
\text { dose budesonide in } 120 \text { children with severe } \\
\text { intermittent wheezing ( } 71 \% \text { had diagnosed } \\
\text { asthma) participating in a } 1 \text {-year multicenter } \\
\text { DB RCT. }\end{array}$ & $1-4.5$ & USA wide & $28-48^{\circ} \mathrm{N}$ & $\begin{array}{l}\text { VDD was correlated with non-white ethnicity } \\
\text { and tobacco exposure. } 25(\mathrm{OH}) \mathrm{D} \text { level at } \\
\text { randomization was not correlated with the rate } \\
\text { of exacerbations requiring OCS therapy over the } \\
\text { 1-year trial. However, VDD participants had a } \\
\text { significantly higher mean rate of exacerbations } \\
\text { requiring OCS compared with non-VDD } \\
\text { participants. }\end{array}$ & {$[13]$} \\
\hline $\begin{array}{l}\text { Prospective study of } 3727 \text { adults followed for } \\
\text { 10y. }\end{array}$ & $30-60$ & $\begin{array}{l}\text { Copenhagen, } \\
\text { Denmark }\end{array}$ & $57^{\circ} \mathrm{N}$ & $\begin{array}{l}\text { No correlation of } 25(\mathrm{OH}) \mathrm{D} \text { with atopy or } \\
\text { asthma. Low } 25(\mathrm{OH}) \mathrm{D} \text { was correlation with } \\
\text { lower \% predicted } \mathrm{FEV}_{1} \text {. Correlation between } \\
\text { high baseline } 25(\mathrm{OH}) \mathrm{D} \text { and adverse changes in } \\
\text { lung function. }\end{array}$ & [156] \\
\hline
\end{tabular}

Abbreviations: $25(\mathrm{OH}) \mathrm{D}=25$-hydroxyvitamin $\mathrm{D}$; $\mathrm{DB}=$ double-blind; $\mathrm{FEV}_{1}=$ forced expiratory volume in $1 \mathrm{~s}$; FVC = forced vital capacity; OCS = oral corticosteroid; $\mathrm{RCT}=$ randomized, controlled trial; VDD = vitamin D deficiency. 
Table 5

Vitamin D intervention studies in asthma.

\begin{tabular}{|c|c|c|c|c|c|c|c|c|}
\hline Design & Duration (weeks) & Population & Dose & Age & Location & Latitude & Main findings & Reference \\
\hline Pilot study & $\begin{array}{l}\text { Varied: weeks to } \\
\text { months }\end{array}$ & $\begin{array}{l}3 \text { non-atopic asthmatic, } \\
2 \text { subjects with chronic } \\
\text { uriticaria and } 6 \text { subjects } \\
\text { with ragweed } \\
\text { allergy + asthma }\end{array}$ & $\begin{array}{l}\text { Up to } 1,380,000 \mathrm{IU} \\
\text { vitamin n } \mathrm{D}_{2} \text { bi- } \\
\text { weekly }\end{array}$ & $\begin{array}{l}\text { Not } \\
\text { specified }\end{array}$ & USA & $\begin{array}{l}\text { Not } \\
\text { specified }\end{array}$ & $\begin{array}{l}\text { Non-atopic asthmatics and subjects } \\
\text { with uriticaria showed little } \\
\text { improvement while subjects with } \\
\text { ragweed allergy showed varying but } \\
\text { obvious improvements }\end{array}$ & [137] \\
\hline Pilot study & $\begin{array}{l}\text { Varied: weeks to } \\
\text { months }\end{array}$ & $\begin{array}{l}212 \text { patients with } \\
\text { ragweed allergy }+ \\
\text { asthma }\end{array}$ & $\begin{array}{l}\text { vitamin } \mathrm{D}_{2} \\
(120,000- \\
300,000 \mathrm{IU} / \\
\text { day }) \pm \text { pollen } \\
\text { injection. }\end{array}$ & $\begin{array}{l}\text { Not } \\
\text { specified }\end{array}$ & USA & $\begin{array}{l}\text { Not } \\
\text { specified }\end{array}$ & $\begin{array}{l}\text { In the viosterol only group, } 82.4 \% \\
\text { improved, while. } 96.5 \% \text { in the } \\
\text { viosterol + pollen group improved }\end{array}$ & [136] \\
\hline Acute, crossover DBRCT & Acute administration & $\begin{array}{l}12 \text { patients with } \\
\text { allergic bronchial } \\
\text { asthma }\end{array}$ & $\begin{array}{l}\text { oral calcium }+ \\
\text { vitamin } D_{2}\end{array}$ & $\begin{array}{l}\text { Not } \\
\text { specified }\end{array}$ & Germany & $\begin{array}{l}\text { Not } \\
\text { specified }\end{array}$ & $\begin{array}{l}\text { Within } 60 \text { min of application, a } \\
\text { statistically significant reduction of } \\
\text { airway resistance and intrathoracic gas } \\
\text { volume, as well as an increase of } \mathrm{FEV}_{1} \\
\text { and forced inspiratory volume in } 1 \mathrm{~s} \\
\left(\mathrm{FIV}_{1}\right) \text { was observed compared to } \\
\text { placebo }\end{array}$ & [161] \\
\hline $\begin{array}{l}3 \text { arm DBRCT to assess the effectiveness } \\
\text { of SIT + steroid vs. SIT, steroid + } \\
\text { vitamin } D_{3} \text { vs. SIT, steroid + placebo }\end{array}$ & 52 & $\begin{array}{l}54 \text { asthmatic children } \\
\text { allergic to house dust } \\
\text { mites on SIT. }\end{array}$ & $\begin{array}{l}1000 \mathrm{IU} \text { vitamin } \mathrm{D}_{3} / \\
\text { week }\end{array}$ & $6-12$ & Lodz, Poland & $52^{\circ} \mathrm{N}$ & $\begin{array}{l}\text { ICS prevented the clinical and } \\
\text { immunological benefits of SIT. The } \\
\text { addition of vitamin D preserved the } \\
\text { benefits of SIT, despite concomitant ICS } \\
\text { use }\end{array}$ & [111] \\
\hline $\begin{array}{l}\text { DBRCT to assess the effectiveness of } \\
\text { vitamin D in reducing influenza A } \\
\text { incidence }\end{array}$ & 16 & $\begin{array}{l}334 \text { Japanese school } \\
\text { children }\end{array}$ & $\begin{array}{l}2000 \text { IU vitamin } \\
D_{3} / \mathrm{d}\end{array}$ & $8-12$ & Japan wide & $34-45^{\circ} \mathrm{N}$ & $\begin{array}{l}42 \% \text { reduction in influenza } \mathrm{A} \text { in vitamin } \\
\mathrm{D} \text { group compared to placebo. In } \\
\text { asthmatics, this was associated with an } \\
83 \% \text { in asthma attacks }\end{array}$ & [160] \\
\hline $\begin{array}{l}\text { DBRCT ICS + vitamin } D_{3} \text { vs. ICS + } \\
\text { placebo }\end{array}$ & 26 & $\begin{array}{l}48 \text { children with newly } \\
\text { diagnosed asthma }\end{array}$ & $500 \mathrm{IU}$ vitamin $\mathrm{D}_{3} / \mathrm{d}$ & $5-18$ & Lodz, Poland & $52^{\circ} \mathrm{N}$ & $\begin{array}{l}\text { Significantly lower risk of asthma } \\
\text { exacerbation in the vitamin D group. No } \\
\text { difference in serum 25(OH)D and ATAQ } \\
\text { scores }\end{array}$ & [112] \\
\hline $\begin{array}{l}\text { DBRCT to examine whether increased } \\
\text { 25(OH)D levels either through } \\
\text { seasonal variations or } \\
\text { supplementation affect asthma }\end{array}$ & 52 & $\begin{array}{l}20 \text { children with } \\
\text { chronic persistent } \\
\text { asthma }\end{array}$ & $\begin{array}{l}1000 \text { IU vitamin } \\
D_{3} / \mathrm{d}\end{array}$ & $6-17$ & Creighton, USA & $42^{\circ} \mathrm{N}$ & $\begin{array}{l}\text { At baseline, 95\% were VDI. Vitamin D } \\
\text { supplementation did not affect ACT } \\
\text { score or FEV } \text { FE }_{1} \text {. However, children were } \\
\text { well controlled at baseline. Pooled data } \\
\text { on all 25(OH)D measurements and } \\
\text { corresponding ACT scores revealed a } \\
\text { significant positive correlation }\end{array}$ & [104] \\
\hline $\begin{array}{l}\text { DBRCT standard treatment + vitamin D } \\
\text { or placebo }\end{array}$ & 26 & $\begin{array}{l}100 \text { childhood } \\
\text { asthmatics }\end{array}$ & $\begin{array}{l}60,000 \text { IU vitamin } \\
D_{3} / \text { month }\end{array}$ & $\begin{array}{l}\text { Not } \\
\text { specified }\end{array}$ & New Delhi, India & $28^{\circ} \mathrm{N}$ & $\begin{array}{l}\text { Significantly lower risk of asthma } \\
\text { exacerbation, steroid requirement and } \\
\text { ED visits in the vitamin D group } \\
\text { accompanied by significantly increased } \\
\text { PEFR }\end{array}$ & {$[183]$} \\
\hline $\begin{array}{l}\text { ICS or ICS plus LABA + vitamin D or } \\
\text { placebo }\end{array}$ & 24 & 130 asthmatics. & $\begin{array}{l}100,00 \text { IU bolus IM } \\
\text { plus } 50,000 \text { IU } \\
\text { orally weekly }\end{array}$ & $10-50$ & Tehran, Iran & $36^{\circ} \mathrm{N}$ & $\begin{array}{l}\% \mathrm{FEV}_{1} \text { improved in both groups but to a } \\
\text { significantly greater degree in the } \\
\text { vitamin } \mathrm{D} \text { group at } 24 \text { weeks }\end{array}$ & [6] \\
\hline $\begin{array}{l}3 \mathrm{arm} \text { RCT of SCIT alone vs. SCIT + } \\
\text { vitamin D vs. pharmacotherapy } \\
\text { alone }\end{array}$ & 52 & $\begin{array}{l}50 \text { childhood } \\
\text { asthmatics sensitized to } \\
\text { house dust mite }\end{array}$ & $\begin{array}{l}650 \text { IU vitamin } D_{3} / \\
\text { day }\end{array}$ & $5-15$ & Istanbul, Turkey. & $41^{\circ} \mathrm{N}$ & $\begin{array}{l}\text { Asthma symptoms were lower in both } \\
\text { SCIT groups compared to } \\
\text { pharmacotherapy alone. However the } \\
\text { vitamin D supplemented group had } \\
\text { greater improvements }\end{array}$ & [12] \\
\hline
\end{tabular}


DBRCT of ICS + vitamin D or ICS placebo 28

Unblinded, uncontrolled pilot
Randomly divided into vitamin D supplementation or

supplementation

Open label, randomized trial of usua
care vs. usual care + vitamin D

roof-of-concept DBRCT of 1,25 as adjunct to prednisolone
408 adults with symptomatic asthma and VDI

28 elderly asthmatics
100,000 IU vitamin $\quad 40 \pm 13 \quad$ USA wide

$\mathrm{D}_{3}$ followed by

2000
Day 1 and 4 post

14

16 VDD asthmatic patients with severe asthma exacerbation $80 \mathrm{mg} /$ day of methylprednisolone fo 7 days. 48 mild to moderate persistent adult asthmatics 24 severe SR asthmatics 4 $7.5 \mathrm{mg}$ vitamin of $\quad 45 \pm 15 \quad$ Sichuan, China.
$\mathrm{D}_{3} \mathrm{IM}$.

?

Not specified

$0.25 \mu \mathrm{g} 1,25 \mathrm{D}$ twice $\quad \mathrm{Not}$ daily

Not
specified
specified
Porur, India.

London, Englan

44 patients with nonatopic asthma with neutrophilic and/or eosinophilic airwa
inflammation.

$28-48^{\circ} \mathrm{N} \quad$ Vitamin D supplementation had no significant effect on the overall rate of significant effect on the overall rate of Significant reductions in exacerbations and the rate of first treatment failure in the $82 \%$ subjects who reached VDS Mean 25(OH)D increased by $24 \mathrm{nmol} / \mathrm{L}$ There was no correlation between 25(OH)D and ICS dose. Vitamin D was significantly lower in subjects with uncontrolled asthma. In uncontrolled asthma, ACT scores increased significantly at the end of the study but spirometry did not change Supplemental vitamin $\mathrm{D}_{3}$ significantly increased the rate of $\% \mathrm{FEV}_{1}$ improvement and decreased airway epithelial ROS as well as DNA damage

\% $\mathrm{FEV}_{1}$ improved in both groups, but to a greater extent in the vitamin $D$ group

No significant difference in \% $\mathrm{FEV}_{1}$ between 1,25 and placebo. Within group comparison of OCS $+1,25$ o placebo revealed a modest but

significant improvement in absolute and predicted $\mathrm{FEV}_{1}$ with $1,25 \mathrm{D}$. There was a trend for a positive correlation between baseline $25(\mathrm{OH}) \mathrm{D}$ and change in predicted lung function following OCS. Following prednisolone, there was a greater improvement in $\% \mathrm{FEV}_{1}$ in VDS
compared to VDI.

Vitamin D did not significantly affect sputum neutrophils or eosinophils compared with placebo. However, sub group analyis po subects with airway signifin vitinin $\mathrm{cos}$ increase in the placebo group. Vitamin increase in the placebo group. Vitami better ACQ scores
[30]

Abbreviations; $\mathrm{ACQ}=$ asthma control questionnaire; $\mathrm{ACT}=$ asthma control test; $\mathrm{ATAQ}=$ asthma therapy assessment questionnaire; $\mathrm{DB}=$ double-blind; $\mathrm{ED}=$ emergency department; FeNO $=$ fractional exhaled nitric oxide; $\mathrm{FEV}_{1}=$ forced expiratory volume in $1 \mathrm{~s}$; hs-CRP = high sensitivity C reactive protein; ICS = inhaled corticosteroid; IFN- $\gamma=$ gamma interferon. IgE = immunoglobulin E; IL = interleukin; IU = international unit; LABA = long-acting $\beta$-agonist; OCS = oral corticosteroid; $\mathrm{PC}_{20^{-}}$FEV $\mathrm{FE}_{1}=$ provocation dose of methacholine require to induce a $20 \%$ drop in $\mathrm{FEV}_{1 ;}$ PEFR $=$ peak expiratory flow rate; RCT $=$ randomized, placebo controlled trial; SCIT = subcutaneous immunotherapy; SIT = specific immunotherapy; VDI = vitamin D insufficiency; VDS = vitamin D sufficiency; VDS = vitamin D sufficiency. 
only $26 \%(n=110)$ of the sample had physician diagnosed asthma. Additionally there was no assessment of $25(\mathrm{OH}) \mathrm{D}$ status or asthma severity at any stage [160].

Following up on their preliminary work, Majak et al. conducted a small, DBRCT of ICS vs. ICS + vitamin D $(500 \mathrm{IU} / \mathrm{d})$. This was a 6 month trial conducted at high latitude $\left(51^{\circ} \mathrm{N}\right)$ and enrolled 48 children with newly diagnosed asthma. There was a significant increase in asthma exacerbations in the placebo group (OR, 8.6; 95\% $\mathrm{CI}, 2.1-34.6)$. However, the difference in serum 25(OH)D and asthma therapy assessment questionnaire (ATAQ) scores between the intervention and placebo group was very small and neither reached statistical significance [112].

Retrospective, secondary analysis of pooled data obtained from previously published DBRCTs on 36 asthmatic children undergoing allergen immunotherapy revealed that higher serum 25(OH)D was associated with a more significant reduction in asthma symptoms and steroid use as well as higher TGF- $\alpha$ production and Foxp3 induction [113].

Lewis et al. conducted a 1 year DBRCT to examine whether increased $25(\mathrm{OH}) \mathrm{D}$ levels - either through seasonal variation or supplementation - could affect asthma. In this one year study of 20 children with chronic persistent asthma, half were given $1000 \mathrm{IU}$ vitamin $\mathrm{D}_{3} / \mathrm{d}$ while the other half were given placebo and seasonal variation in 25(OH)D was observed. 19 of the 20 enrolled children were VDI at baseline. Although, vitamin D supplementation did not affect ACT score or $\mathrm{FEV}_{1}$, all children were well controlled at baseline. Further, pooled data on all 25(OH)D measurements and corresponding ACT scores revealed a significant positive correlation $(r=0.25, \mathrm{p}<0.05)[104]$.

Yadav \& Mittal conducted a DBRCT to assess the effectiveness of vitamin $\mathrm{D}_{3}(60,000 \mathrm{IU} /$ month $)$ vs. placebo in improving asthma parameters. Compared to the placebo group, the vitamin $\mathrm{D}$ group experienced reduced exacerbations $(\mathrm{p}=0.011)$ and steroid requirements $(\mathrm{p}=0.013)$ and increased expiratory flow rate, however there was no report of $25(\mathrm{OH}) \mathrm{D}$ levels. The authors concluded: 'Vitamin D has a definite role in the management of moderate to severe persistent bronchial asthma as an adjunct to standard treatment' [183].

Arshi et al. conducted a 3 arm randomized trial of ICS vs. ICS plus long-acting $\beta$-agonist (LABA) + vitamin $\mathrm{D}_{3}$ vs. ICS plus LABA + placebo. This 24 week trial included asthmatics aged $10-50 \mathrm{y}$ and the vitamin D dose was 100,00 IU bolus intramuscularly (IM) plus 50,000 IU orally weekly. Although, percentage predicted $\mathrm{FEV}_{1}$ improved in both groups, the improvement was significantly greater in the vitamin D group at 24 weeks $(p<0.001)$ [6].

Baris et al. conducted a $3 \mathrm{arm}$, randomized trial of subcutaneous immunotherapy (SCIT) alone $(n=15)$, or with vitamin $D_{3}$ supplementation (650 IU/day; $n=17)$, or pharmacotherapy alone $(n=18)$. Although both SCIT groups fared better than pharmacotherapy alone at the end of 1 year, some favorable outcomes in the vitamin $\mathrm{D}$ group were noted including better asthma controls as indicated by corticosteroid treatment discontinuation in a greater percentage of patients $(\mathrm{p}=0.02)[12]$.

Bar Yoseph et al. conducted a DBRCT of vitamin D supplementation (14,000 IU/week) vs. placebo for 6 weeks in asthmatic children. There was no change in IgE, eosinophil count, high sensitivity $C$ reactive protein, fraction of exhaled nitric oxide levels or provocation dose of methacholine require to induce a 20\% drop in $\mathrm{FEV}_{1}$ between he vitamin D or placebo groups. Exhaled breath condensate cytokines, including IL4, IL5, IL10, IL17, and interferon gamma changed in both groups but there was no difference [11].

Castro et al. reported findings from the large Vitamin D Add-on Therapy Enhances Corticosteroid Responsiveness in Asthma (VIDA). Compared to placebo, a baseline $100,000 \mathrm{IU}$ vitamin $\mathrm{D}_{3}$ bolus followed by 4000 IU daily for 28 weeks had no significant effect on the overall rate of first treatment failure or exacerbation in patients with asthma and VDI. However, at 28 weeks, there was a significant difference in cumulative ciclesonide (a glucocorticoid) dosing between the vitamin D and placebo groups (111.3 vs. $126.2 \mu \mathrm{g} /$ day; $\mathrm{p}=0.02$ ). Additionally, in the $82 \%$ of the vitamin $\mathrm{D}$ supplementation group who reached VDS, there were significant reductions in exacerbations and the rate of first treatment failure [30]. Due to the baseline bolus dose and the moderate-high daily dose, it was surprising that $18 \%$ of the vitamin D group did not reach VDS, which may have affected the results. This may be due to the obese nature of the cohort (mean BMI $=32 \mathrm{~kg} / \mathrm{m}^{2}$ ) or malabsorption, metabolism, or compliance issues with vitamin D.

Columbo et al. conducted an unblinded, uncontrolled pilot study to assess the potential effect of vitamin D in elderly asthmatics. This 12 week study included 28 elderly asthmatics ( $>65 \mathrm{y}$ ) adjunctly treated with 2000 IU vitamin $\mathrm{D}_{3}$ daily. There was no association between 25(OH)D and ICS dose or spirometric values. However, 25OH)D was significantly lower in subjects with uncontrolled asthma and in uncontrolled asthma, ACT scores increased significantly at the end of the study $(\mathrm{p}<0.04)$.

Lan et al. conducted an unblinded pilot study to assess the acute effects of $80 \mathrm{mg} /$ day of methylprednisolone alone vs. combined with $7.5 \mathrm{mg}$ intramuscular vitamin $\mathrm{D}_{3}$ injection in vitamin $\mathrm{D}$ deficient adults (in this study: $<75 \mathrm{nmol} / \mathrm{L}$ ) with severe asthma exacerbation. Vitamin $D_{3}$ injections were given on day 1 and day 4 . The supplemental vitamin $\mathrm{D}_{3}$ significantly increased the rate of $\% \mathrm{FEV}_{1}$ improvement and decreased reactive oxygen species as well as DNA damage compared to monotherapy with methylprednisolone [100].

Nageswari et al. conducted an open labeled, RCT of usual care (budesonide and formoterol) vs. usual care + vitamin $\mathrm{D}_{3}$ (1000 IU/ day). Although this trial was short (90 days) and included a small cohort $(\mathrm{n}=48)$, an increase in $\%$ predicted $\mathrm{FEV}_{1}$ was observed in the usual care + vitamin D group compared to the usual care only group [125].

Nanzer et al. conducted a proof-of-concept DBRCT of 1,25D as adjunct to prednisolone in 24 severe SR asthmatics. $0.25 \mu \mathrm{g} 1,25 \mathrm{D}$ was administered twice daily to the $1,25 \mathrm{D}$ group $(\mathrm{n}=13)$. Although there was no significant difference in $\% \mathrm{FEV}_{1}$, a within-group comparison showing the change in lung function during the initial screening in response to 2-week oral prednisolone vs. the response to an identical course of prednisolone plus either placebo or $1,25 \mathrm{D}$ revealed a modest but significant improvement in absolute and predicted $\mathrm{FEV}_{1}$ with $1,25 \mathrm{D}$ compared to placebo $(\mathrm{p}=0.03$ ). There was no observed benefit in patients randomized to receive $1,25 \mathrm{D}$ before the second course of prednisolone, suggesting that 1,25D alone had no effect on lung function. A trend for a positive correlation between baseline $25(\mathrm{OH}) \mathrm{D}$ and change in predicted lung function following prednisolone $(r=0.56, \mathrm{p}=0.08)$ was observed. Additionally, following prednisolone, there was a greater improvement in $\% \mathrm{FEV}_{1}$ in VDS compared to VDI subjects $(\mathrm{p}=0.03)$ [126].

de Groot et al. conducted a DBRCT comparing a large bolus of vitamin $\mathrm{D}_{3}(400,000 \mathrm{IU})$ to placebo. On a group level, there was no significantly effect on sputum neutrophils or eosinophils with vitamin D or placebo. However, subgroup analysis of subjects with airway eosinophilia at baseline revealed that vitamin D significantly decreased sputum eosinophils from a median of $41 \%-11.8 \%$ compared to an increase from $51.8 \%$ to $63.3 \%$ in patients receiving placebo $(\mathrm{p}=0.034)$. Vitamin $\mathrm{D}$ treatment also resulted in slightly better Asthma Control Questionnaire scores $(p=0.08)$ [43].

Although some of these interventional trials suggest a benefit of vitamin D repletion, they are limited by small sample sizes, short duration and potentially inadequate vitamin D dose. Nevertheless, a recent systematic review and meta-analysis in paediatric asthmatics noted a statistically significant reduction in asthma 
exacerbation with vitamin D supplementation (RR $0.41, \mathrm{CI}$ $0.27-0.63$ ) [134]. However, the need for adequately powered trials utilizing adequate vitamin $\mathrm{D}$ dosing persists.

\subsection{Why is data from human studies inconsistent?}

The majority of existing epidemiologic and observational data suggest that vitamin D intake and/or status may be of importance in asthmatic disease. However, not all studies are in agreement with some studies demonstrating no benefit from increased vitamin D intake and/or status, while other reports suggest inferior asthmatic outcomes associated with higher vitamin D. Vitamin D represents a unique nutrient with many complexities. Although some studies directly measure vitamin D status, other studies record vitamin $\mathrm{D}$ intake through food frequency questionnaires, which can be a poor predictor of both vitamin D intake and $25(\mathrm{OH})$ D status. Unlike other nutrients, the major source of vitamin D for most people is not through diet, but from exposure to UV-B. Therefore vitamin D status displays marked variation depending on local weather conditions and individual sun behaviors e.g. sunscreen use, time indoors etc. Most studies assess sun habits and vitamin $\mathrm{D}$ status or intake at a single time point only. Human behavior and season are variables, which change often and can influence both asthma and vitamin D outcomes. Therefore epidemiologic and observational studies are limited regarding asthma and vitamin $\mathrm{D}$.

Well designed, long term prospective and interventional studies regarding vitamin $\mathrm{D}$ and asthmatic disease can provide more robust evidence. To date there is a lack of these studies in asthma (reviewed in Tables 4 and 5 respectively). However, again the results of existing prospective studies are conflicting. These prospective studies have relied on a single measurement of vitamin D status or intake with asthmatic outcomes assessed up to 31 years later. Despite efforts to control for relevant, non-vitamin D confounders, it is impossible to discount variables other than vitamin D contributing to the observations. Similarly, vitamin D intervention studies to date provide inconsistent results. There have been 17 vitamin $\mathrm{D}$ intervention trials in asthma to date (Table 5). These intervention trials differed in terms of trial design, vitamin D dosing, outcome measures and trial duration, which may help explain the inconsistencies.

\section{Conclusions}

\subsection{What is the optimal vitamin D intakes and serum $25(\mathrm{OH})$ level for asthma?}

The recommendations for optimal vitamin $\mathrm{D}$ intake and serum 25(OH)D levels are controversial. The 2010 IOM report suggests a recommended daily allowance of $600 \mathrm{IU}$ for healthy subjects aged $>1 \mathrm{y}$ and a target serum 25(OH)D of $>50 \mathrm{nmol} / \mathrm{L}$ [139]. However this report was based almost exclusively on skeletal considerations and has been criticized by experts in the vitamin D field [69,167]. Some reports observed a plateau effect of serum 25(OH)D at $50 \mathrm{nmol} / \mathrm{L}$ regarding exacerbations in asthmatics [13]. However, others suggest a serum $25(\mathrm{OH}) \mathrm{D}$ level $>100 \mathrm{nmol} / \mathrm{L}$ may be required for optimal immunological and respiratory outcomes $[17,76,78,79,166]$. Conversely, both high and low 25(OH)D levels have been associated with adverse outcomes in terms of increased aeroallergen sensitization [140], elevated IgE levels [83], and adverse changes in lung function [156] raising the possibility that an optimal level of $25(\mathrm{OH})$ D exists regarding asthma and that levels above or below are detrimental.

It has been argued that in populations with limited sun exposure that the current vitamin D recommendations are inadequate for non-skeletal effects, and that intakes $\geq 2000 \mathrm{IU} /$ day may be required [74,76]. For example, a 500 IU supplement of vitamin $\mathrm{D}_{3}$ daily for 6 months was insufficient to increase serum 25(OH)D in asthmatic children at $51^{\circ} \mathrm{N}$ [113]. In asthmatic children treated with 1000 IU for 12 months only $50 \%$ reached vitamin D sufficiency defined as $>75 \mathrm{nmol} / \mathrm{L}$ [104]. Indeed, the Endocrine Society recommended vitamin D supplements of up to $4000 \mathrm{IU} /$ day for adults [76].

UV-B is the major source of vitamin D for most people, even at high latitude [74] but with lifestyle changes and concerns about sun damage, sun exposure has decreased contributing to widespread VDI. However, achievable sunlight exposure may not be sufficient for adequate 25(OH)D levels, particularly in urban and/or heavily pigmented subjects [21]. Because vitamin D is naturally found in few foods (mainly oily fish) and few food products are fortified adequately (mainly dairy and cereal products), it is difficult to achieve an adequate vitamin D status through diet al.one. Indeed, dietary intake of vitamin D is typically inadequate [18], including among asthmatic cohorts [25]. Further, a randomized controlled trial demonstrated that diet was inadequate to achieve sufficient serum 25(OH)D [41].

Although cod liver oil contains vitamin $\mathrm{D}_{3}$, its use has been associated with increased asthma incidence $[81,110,129]$ possibly due to its high vitamin D content [27] and therefore may not represent a suitable vehicle to increase vitamin $D$ intake and serum $25(\mathrm{OH}) \mathrm{D}$. Additionally, vitamin $\mathrm{D}_{2}$ is not as effective as vitamin $\mathrm{D}_{3}$ in maintaining serum 25(OH) levels [159].

\subsection{Future recommendations}

Despite, recent widespread publicity, vitamin D deficiency remains highly prevalent throughout the world [74]. Here we have presented human observational and interventional data regarding vitamin D and asthma. Despite the recent advances in our understanding of the vitamin D pathway and its potential implications for allergic and immune disorders such as asthma, many questions remain:

- Is widespread vitamin D supplementation detrimental in asthma as initially hypothesized or beneficial as mechanistic and observational work suggest?

- Has vitamin D replacement therapy a role as an adjunct to antiinflammatory therapy or immunotherapy in asthma?

- Is the effect of vitamin D supplementation limited to a specific asthma phenotype/endotype? And if so, which one?

- When is the therapeutic age range to exploit the potential benefits of vitamin D supplementation in asthma?

- Should $25(\mathrm{OH}) \mathrm{D}$ be routinely measured in asthma?

- What is the desired serum 25(OH)D level for a potential therapeutic effect in asthma?

- What is the best strategy to achieve this desired serum 25(OH)D level?

- Does peri-natal vitamin D supplementation reduce the risk of developing asthma? The focus of the current manuscript was to review existing human evidence that vitamin $\mathrm{D}$ may be of importance in asthmatic disease. We have not comprehensively reviewed studies of perinatal studies of vitamin D status or intake. Existing trials in this area are inconsistent, probably owing to important differences in study design for example measuring vitamin D status versus reported vitamin D intake. Additionally vitamin D levels are known to fluctuate over time and are rapidly and significantly altered by modifiable human behaviors such as location, sun behaviors and supplement use. Therefore, the importance of a single vitamin D assessment in early childhood or pregnancy is of debatable importance 
regarding future asthmatic outcomes. However manipulating $25(\mathrm{OH}) \mathrm{D}$ status holds promise for primary prevention of asthma as recent reviews suggest $[121,135]$.

- Is ultraviolet radiation a powerful immunomodulator in asthmatic disease where $25(\mathrm{OHJ})$ D status merely reflects ultraviolet exposure? For example acute ultraviolet exposure caused systemic immunosuppression in the absence of increased 25(OH)D in mice [64] This fascinating concept cannot be discounted currently and is supported by several, recent animal studies whereby ultraviolet exposure inhibited asthmatic disease $[117,118]$. Relevant human evidence comes from inverse associations with diverse respiratory tract symptoms [155], RSV incidence [172,186] and risk of invasive pneumococcal disease associated with UV-B (White et al., 2009). We briefly presented human evidence suggesting a benefit of sunlight in asthmatic disease above in section 3.1.2

New therapeutic options for wheezing disorders, and particularly steroid resistant asthma are needed. Serum 25(OH)D level is a novel and modifiable potential risk marker for severe asthma exacerbations [55]. Taken together existing mechanistic and observational data support a role for vitamin $\mathrm{D}$ as an important factor in asthma and infection. However, results from existing clinical trials provide heterogeneous findings.

Vitamin D supplementation potentially represents a low-cost, low-risk method to treat and prevent asthma and therefore further exploration of the effect of vitamin D supplementation is encouraged. Future trials should utilize adequate doses of vitamin $D_{3}$ preparations for interventions of sufficient duration. Appropriate trial duration appears likely to be $>12$ months considering the half life of $25(\mathrm{OH}) \mathrm{D}$ is approximately $2-3$ weeks [75] as well as the natural seasonal variation in asthma and infection. Additionally, because reported vitamin $D$ intake and sun exposure are unreliable, $25(\mathrm{OH}) \mathrm{D}$ should be measured, preferably on more than one occasion. This will also help determine optimal 25(OH)D levels and decrease risk of vitamin D toxicity (VDT). VDT is rare and has most reports of VDT have resulted from industrial accidents [4]. Nevertheless supraphysiological 25(OH)D levels ( $>375 \mathrm{nmol} / \mathrm{L}$ ), which are a possibility with extended use of inappropriately high doses of vitamin $\mathrm{D}(\geq 10,000 \mathrm{IU} / \mathrm{d})$, can cause hypercalcemia and increased risk of falls [144].

The data reviewed herein suggest that supplementation with moderate doses (e.g. $1000 \mathrm{IU} / \mathrm{d}$ ) of vitamin $\mathrm{D}_{3}$ may be appropriate for maintenance of bone health in asthmatics, particularly steroid users. However, existing data does not yet definitively support a role for supplemental vitamin D therapy as a adjunct strategy in asthmatic disease. Despite limited evidence, an adverse effect of widespread vitamin D supplementation can not be discounted and therefore caution is advised until more definitive evidence is available.

Childhood asthma and steroid resistant asthma are key underexplored areas where vitamin $\mathrm{D}$ based interventions may provide benefit. Only the results of well-designed, clinical trials can elude as to effects of vitamin D therapy asthma. Indeed there has been a call to action for well-designed intervention trials of vitamin D supplementation to assess its role in preventing and treating asthma [47]. Ongoing longitudinal studies and clinical trials should help ultimately answer some of the existing questions.

\section{Author contributions}

- CK made substantial contributions to review design and manuscript collection and interpretation of data; has drafted the submitted article; has provided final approval of the version to be published; and has agreed to be accountable for all aspects of the work in ensuring that questions related to the accuracy or integrity of any part of the work are appropriately investigated and resolved.

- BE revised the submitted article critically for important intellectual content; has provided final approval of the version to be published.

- JF revised the submitted article critically for important intellectual content; has provided final approval of the version to be published.

- LC revised the submitted article critically for important intellectual content; has provided final approval of the version to be published. and has agreed to be accountable for all aspects of the work in ensuring that questions related to the accuracy or integrity of any part of the work are appropriately investigated and resolved

\section{Role of the sponsors}

The sponsors were not involved in the design, analysis or reporting of the current trial.

\section{Funding information}

CK is supported by funding from the Asthma Society of Ireland, National Children's Hospital Foundation, Irish Thoracic Society, and the Irish Lung Foundation. The funding bodies had no involvement in study design, data collection, analysis or interpretation.

\section{Acknowledgments}

Guarantor statement: CK and LC guarantee the accuracy and completeness of the reported data, and for the fidelity of the study.

\section{References}

[1] Afzal S, Lange P, Bojesen SE, Freiberg JJ, Nordestgaard BG. Plasma 25hydroxyvitamin D, lung function and risk of chronic obstructive pulmonary disease. Thorax 2014:69:24-31.

[2] Akinbami LJ. The State Of Childhood Asthma, United States, 1980-2005. Advance data from vital and health statistics. No. 381. U.S. Department of Health and Human Services, Centers for Disease Control and Prevention, National Center for Health Statistics; 2006., http://www.cdc.gov/nchs/data/ ad/ad381.pdf.

[3] Alyasin S, Momen T, Kashef S, Alipour A, Amin R. The relationship between serum 25 hydroxy vitamin d levels and asthma in children. Allergy Asthma Immunol Res 2011;3:251-5.

[4] Araki T, Holick MF, Alfonso BD, Charlap E, Romero CM, Rizk D, et al. Vitamin D intoxication with severe hypercalcemia due to manufacturing and labeling errors of two dietary supplements made in the United States. J Clin Endocrinol Metab 2011;96:3603-8.

[5] Arnedo-Pena A, Garcia-Marcos L, Fernandez-Espinar JF, Bercedo-Sanz A, Aguinaga-Ontoso I, Gonzalez-Diaz C, et al. Sunny hours and variations in the prevalence of asthma in schoolchildren according to the International Study of Asthma and Allergies (ISAAC) Phase III in Spain. Int J Biometeorol 2011;55: of Asthmis.

[6] Arshi S, Fallahpour M, Nabavi M, Bemanian MH, Javad-Mousavi SA, Nojomi M, et al. The effects of vitamin D supplementation on airway functions in mild to moderate persistent asthma. Ann Allergy Asthma Immunol: Off Publ Am Coll Allergy Asthma Immunol 2014;113:404-9.

[7] Awasthi S, Vikram K. Serum 25 hydroxy vitamin D insufficiency associated with bronchial asthma in Lucknow, India. Indian J Pediatr 2014:81:644-9.

[8] Bäck O, Blomquist HK, Hernell O, Stenberg B. Does vitamin D intake during infancy promote the development of atopic allergy? Acta Derm Venereol 2009;89:28-32.

[9] Baiz N, Dargent-Molina P, Wark JD, Souberbielle JC, Slama R, AnnesiMaesano I. Gestational exposure to urban air pollution related to a decrease in cord blood vitamin d levels. J Clin Endocrinol Metab 2012:97:4087-95.

[10] Banihosseini SZ, Baheiraei A, Shirzad N, Heshmat R, Mohsenifar A. The effect of cigarette smoke exposure on vitamin $\mathrm{D}$ level and biochemical parameters of mothers and neonates. J Diabetes Metab Disord 2013;12:19.

[11] Bar Yoseph R, Livnat G, Schnapp Z, Hakim F, Dabbah H, Goldbart A, et al. The effect of vitamin $D$ on airway reactivity and inflammation in asthmatic children: a double-blind placebo-controlled trial. Pediatr Pulmonol 2014. http://dx.doi.org/10.1002/ppul.23076. 
[12] Baris S, Kiykim A, Ozen A, Tulunay A, Karakoc-Aydiner E, Barlan IB. Vitamin D as an adjunct to subcutaneous allergen immunotherapy in asthmatic children sensitized to house dust mite. Allergy 2014;69:246-53.

[13] Beigelman A, Zeiger RS, Mauger D, Strunk RC, Jackson DJ, Martinez FD, et al. The association between vitamin D status and the rate of exacerbations requiring oral corticosteroids in preschool children with recurrent wheezing. J Allergy Clin Immunol 2014;133:1489-92. 92.e1-3.

[14] Bener A, Ehlayel MS, Bener HZ, Hamid Q. The impact of vitamin D deficiency on asthma, allergic rhinitis and wheezing in children: an emerging public health problem. J Fam Community Med 2014;21:154-61.

[15] Bener A, Ehlayel MS, Tulic MK, Hamid Q. Vitamin D deficiency as a strong predictor of asthma in children. Int Archiv Allergy Immunol 2012;157: $168-75$.

[16] Berry DJ, Hesketh K, Power C, Hypponen E. Vitamin D status has a linear association with seasonal infections and lung function in British adults. $\mathrm{Br} \mathrm{J}$ Nutr 2011;106:1433-40

[17] Bischoff-Ferrari HA, Giovannucci E Willett WC Dietrich T, DawsonHughes B. Estimation of optimal serum concentrations of 25-hydroxyvitamin D for multiple health outcomes. Am J Clin Nutr 2006;84:18-28.

[18] Black LJ, Walton J, Flynn A, Kiely M. Adequacy of vitamin D intakes in children and teenagers from the base diet, fortified foods and supplements. Public Health Nutr 2014;17:721-31.

[19] Black PN, Scragg R. Relationship between serum 25-hydroxyvitamin d and pulmonary function in the third national health and nutrition examination survey. Chest 2005;128:3792-8.

[20] Bonanno A, Gangemi S, La Grutta S, Malizia V, Riccobono L, Colombo P, et al. 25-Hydroxyvitamin D, IL-31, and IL-33 in children with allergic disease of the airways. Mediat Inflamm 2014;2014:520241.

[21] Bose S, Breysse PN, McCormack MC, Hansel NN, Rusher RR, Matsui E, et al. Outdoor exposure and vitamin D levels in urban children with asthma. Nutr J 2013;12:81.

[22] Brehm JM, Acosta-Perez E, Klei L, Roeder K, Barmada M, Boutaoui N, et al. Vitamin D insufficiency and severe asthma exacerbations in Puerto Rican children. Am J Respir Crit Care Med 2012;186:140-6.

[23] Brehm JM, Celedon JC, Soto-Quiros ME, Avila L, Hunninghake GM, Forno E, et al. Serum vitamin D levels and markers of severity of childhood asthma in Costa Rica. Am J Respir Crit Care Med 2009;179:765-71.

[24] Brehm JM, Schuemann B, Fuhlbrigge AL, Hollis BW, Strunk RC, Zeiger RS, et al. Serum vitamin D levels and severe asthma exacerbations in the Childhood Asthma Management Program study. J Allergy Clin Immunol 2010;126:52-8. e5.

[25] Bueso AK, Berntsen S, Mowinckel P, Andersen LF, Lodrup Carlsen KC, Carlsen KH. Dietary intake in adolescents with asthma-potential for improvement. Pediatr Allergy Immunol: Off Publ Eur Soc Pediatr Allergy Immunol 2011:22:19-24.

[26] Byremo G, Rod G, Carlsen KH. Effect of climatic change in children with atopic eczema. Allergy 2006;61:1403-10.

[27] Cannell JJ, Vieth R, Willett W, Zasloff M, Hathcock JN, White JH, et al. Cod liver oil, vitamin A toxicity, frequent respiratory infections, and the vitamin D deficiency epidemic. Ann Otol rhinol Laryngol 2008:117:864-70.

[28] Canon P. The therapy of nasal allergy; results obtained by high dose vitamin D therapy and calcium. Acta Oto-rhino-laryngologica Belg 1951;5: 495-508.

[29] Carraro S, Giordano G, Reniero F, Carpi D, Stocchero M, Sterk PJ, et al. Asthma severity in childhood and metabolomic profiling of breath condensate. Allergy 2013;68:110-7.

[30] Castro M, King TS, Kunselman SJ, Cabana MD, Denlinger L, Holguin F, et al. Effect of vitamin D3 on asthma treatment failures in adults with symptomatic asthma and lower vitamin D levels: the VIDA randomized clinical trial. Jama 2014;311:2083-91.

[31] Chambers ES, Nanzer AM, Richards DF, Ryanna K, Freeman AT, Timms PM, et al. Serum 25-dihydroxyvitamin D levels correlate with CD4(+)Foxp3(+) Tcell numbers in moderate/severe asthma. J allergy Clin Immunol 2012;130: 542-4.

[32] Checkley W, Robinson CL, Baumann LM, Hansel NN, Romero KM, Pollard SL, et al. 25-hydroxy vitamin D levels are associated with childhood asthma in a population-based study in Peru. Clin Exp Allergy: J Br Soc Allergy Clin Immunol 2015;45:273-82.

[33] Chen L, Perks KL, Stick SM, Kicic A, Larcombe AN, Zosky G. House dust mite induced lung inflammation does not alter circulating vitamin D levels. PloS One 2014;9:e112589.

[34] Cheng HM, Kim S, Park GH, Chang SE, Bang S, Won CH, et al. Low vitamin D levels are associated with atopic dermatitis, but not allergic rhinitis, asthma, or IgE sensitization, in the adult Korean population. J Allergy Clin Immunol 2014; 133:1048-55.

[35] Chinellato I, Piazza M, Sandri M, Peroni D, Piacentini G, Boner AL. Vitamin D serum levels and markers of asthma control in Italian children. J Pediatr 2011;158:437-41.

[36] Chinellato I, Piazza M, Sandri M, Peroni DG, Cardinale F, Piacentini GL, et al. Serum vitamin D levels and exercise-induced bronchoconstriction in children with asthma. Eur Respir J 2011;37:1366-70.

[37] Choi CJ, Seo M, Choi WS, Kim KS, Youn SA, Lindsey T, et al. Relationship between serum 25-hydroxyvitamin D and lung function among Korean adults in Korea National Health and Nutrition Examination Survey (KNHANES), 2008-2010. J Clin Endocrinol Metab 2013;98:1703-10.
[38] Clemens TL, Adams JS, Henderson SL, Holick MF. Increased skin pigment reduces the capacity of skin to synthesise vitamin D3. Lancet 1982;1:74-6.

[39] Columbo M, Panettieri Jr RA, Rohr AS. Asthma in the elderly: a study of the role of vitamin D. Allergy Asthma Clin Immunol: Off J Can Soc Allergy Clin Immunol 2014;10:48.

[40] Confino-Cohen R, Brufman I, Goldberg A, Feldman BS. Vitamin D, asthma prevalence and asthma exacerbations: a large adult population-based study. Allergy 2014;69:1673-80.

[41] Cosenza L, Pezzella V, Nocerino R, Di Costanzo M, Coruzzo A, Passariello A, et al. Calcium and vitamin D intakes in children: a randomized controlled trial. BMC Pediatr 2013;13:86.

[42] Cremers E, Thijs C, Penders J Jansen E, Mommers M. Maternal and child's vitamin D supplement use and vitamin D level in relation to childhood lung function: the KOALA Birth Cohort Study. Thorax 2011;66:474-80.

[43] de Groot JC, van Roon EN, Storm H, Veeger NJ, Zwinderman AH, Hiemstra PS, et al. Vitamin D reduces eosinophilic airway inflammation in nonatopic asthma. J Allergy Clin Immunol 2015;135:670-5.

[44] de Montis G, Gendrel D, Chemillier-Truong M, Dupont C. Sensitisation to peanut and vitamin D oily preparations. Lancet 1993;341:1411.

[45] de Montis G, Truong M, Toussaint B, Berman D, Toudoire C. Peanut sensitization and oily solution vitamin preparations. Arch Pediatr Organe Off la Soc Francaise Pediatr 1995;2:25-8.

[46] Demirel S, Guner SN, Celiksoy MH, Sancak R. Is vitamin D insufficiency to blame for recurrent wheezing? Int Forum Allergy Rhinol 2014;4: 980-5.

[47] Devereux G, Macdonald H, Hawrylowicz C. Vitamin D and asthma: time for intervention? Am J Respir Crit Care Med 2009;179:739-40.

[48] Devereux G, Wilson A, Avenell A, McNeill G, Fraser WD. A case-control study of vitamin D status and asthma in adults. Allergy 2010;65:666-7.

[49] Devgun MS, Paterson CR, Johnson BE, Cohen C. Vitamin D nutrition in relation to season and occupation. Am J Clin Nutr 1981;34:1501-4.

[50] Dogru M, Kirmizibekmez H, Yesiltepe Mutlu RG, Aktas A, Ozturkmen S. Clinical effects of vitamin D in children with asthma. Int Archiv allergy Immunol 2014;164:319-25.

[51] Drincic AT, Armas LA, Van Diest EE, Heaney RP. Volumetric dilution, rather than sequestration best explains the low vitamin D status of obesity. Obesity (Silver Spring, Md) 2012;20:1444-8.

[52] Dyson A, Pizzutto SJ, MacLennan C, Stone M, Chang AB. The prevalence of vitamin D deficiency in children in the Northern Territory. J Paediatr Child health 2014:50:47-50.

[53] Ehlayel MS, Bener A, Sabbah A. Is high prevalence of vitamin D deficiency evidence for asthma and allergy risks? Eur Ann Allergy Clin Immunol 2011;43:81-8.

[55] Forno E, Celedon JC. Predicting asthma exacerbations in children. Curr Opin Pulm Med 2012;18:63-9.

[56] Franco JM, Gurgel R, Sole D, Lucia Franca V, Brabin B. Socio-environmental conditions and geographical variability of asthma prevalence in Northeast Brazil. Allergol Immunopathol 2009;37:116-21.

[57] Freishtat RJ, Iqbal SF, Pillai DK, Klein CJ, Ryan LM, Benton AS, et al. High prevalence of vitamin D deficiency among inner-city African American youth with asthma in Washington, DC. J Pediatr 2010;156:948-52.

[58] Frieri M, Valluri A. Vitamin D deficiency as a risk factor for allergic disorders and immune mechanisms. Allergy Asthma Proc: Off J Regional State Allergy Soc 2011;32:438-44.

[59] Gale CR, Robinson SM, Harvey NC, Javaid MK, Jiang B, Martyn CN, et al. Maternal vitamin D status during pregnancy and child outcomes. Eur J Clin Nutr 2008;62:68-77.

[60] Garcia-Marcos L, Carvajal Uruena I, Escribano Montaner A, Fernandez Benitez M, Garcia de la Rubia S, Tauler Toro E, et al. Seasons and other factors affecting the quality of life of asthmatic children. J Investig Allergol Clin Immunol 2007;17:249-56.

[61] Gergen PJ, Teach SJ, Mitchell HE, Freishtat RF, Calatroni A, Matsui E, et al. Lack of a relation between serum 25-hydroxyvitamin D concentrations and asthma in adolescents. Am J Clin Nutr 2013:97:1228-34.

[62] Ginde AA, Espinola JA, Camargo Jr CA. Improved overall trends but persistent racial disparities in emergency department visits for acute asthma, 19932005. J Allergy Clin Immunol 2008;122:313-8.

[63] Goleva E, Searing DA, Jackson LP, Richers BN, Leung DY. Steroid requirements and immune associations with vitamin $\mathrm{D}$ are stronger in children than adults with asthma. J Allergy Clin Immunol 2012;129:1243-51.

[64] Gorman S, Scott NM, Tan DH, Weeden CE, Tuckey RC, Bisley JL, et al. Acute erythemal ultraviolet radiation causes systemic immunosuppression in the absence of increased 25-hydroxyvitamin D3 levels in male mice. PloS One 2012;7:e46006.

[65] Grant EN, Lyttle CS, Weiss KB. The relation of socioeconomic factors and racial/ethnic differences in US asthma mortality. Am J Public Health 2000;90: 1923-5.

[66] Gupta A, Sjoukes A, Richards D, Banya W, Hawrylowicz C, Bush A, et al. Relationship between serum vitamin $\mathrm{D}$, disease severity, and airway remodeling in children with asthma. Am J Respir Crit Care Med 2011;184:1342-9.

[67] Gupta A, Dimeloe S, Richards DF, Bush A, Saglani S, Hawrylowicz CM. Vitamin D binding protein and asthma severity in children. J Allergy Clin Immunol 2012;129:1669-71.

[68] Gutierrez OM, Farwell WR, Kermah D, Taylor EN. Racial differences in the relationship between vitamin $\mathrm{D}$, bone mineral density, and parathyroid 
hormone in the National Health and Nutrition Examination Survey. Osteoporos Int: I Estab as result Coop between Eur Found Osteoporos Nat Osteoporos Found U S A 2011;22:1745-53.

[69] Heaney RP, Holick MF. Why the IOM recommendations for vitamin D are deficient. J Bone Min Res: Off J Am Soc Bone Min Res 2011;26:455-7.

[70] Heaney RP. Serum 25-hydroxyvitamin D is a reliable indicator of vitamin D status. Am J Clin Nutr 2011;94:619-20. author reply 20.

[71] Heimbeck I, Wjst M, Apfelbacher CJ. Low vitamin D serum level is inversely associated with eczema in children and adolescents in Germany. Allergy 2013;68:906-10.

[72] Hintzpeter B, Scheidt-Nave C, Muller MJ, Schenk L, Mensink GB. Higher prevalence of vitamin D deficiency is associated with immigrant background among children and adolescents in Germany. J Nutr 2008;138:1482-90.

[73] Hirani V, Cumming RG, Blyth FM, Naganathan V, Le Couteur DG Handelsman DJ, et al. Vitamin D status among older community dwelling men living in a sunny country and associations with lifestyle factors: the Concord Health and Ageing in Men Project, Sydney, Australia. J Nutr Health Aging 2013;17:587-93.

[74] Holick MF. Vitamin D deficiency. N. Engl J Med 2007;357:266-81.

[75] Holick MF. Vitamin D status: measurement, interpretation, and clinical application. Ann Epidemiol 2009;19:73-8.

[76] Holick MF, Binkley NC, Bischoff-Ferrari HA, Gordon CM, Hanley DA, Heaney RP, et al. Evaluation, treatment, and prevention of vitamin D deficiency: an Endocrine Society clinical practice guideline. J Clin Endocrino Metab 2011;96:1911-30.

[77] Hollams EM, Hart PH, Holt BJ, Serralha M, Parsons F, de Klerk NH, et al. Vitamin D and atopy and asthma phenotypes in children: a longitudinal cohort study. Eur Respir J 2011;38:1320-7.

[78] Hollis BW, Wagner CL, Drezner MK, Binkley NC. Circulating vitamin D3 and 25-hydroxyvitamin D in humans: an important tool to define adequate nutritional vitamin D status. J Steroid Biochem Mol Biol 2007:103:631-4.

[79] Hollis BW. Assessment of vitamin D status and definition of a normal circulating range of 25-hydroxyvitamin D. Curr Opin Endocrinol Diabetes, Obes 2008;15:489-94.

[80] Hoyos-Bachiloglu R, Morales PS, Cerda J, Talesnik E, Gonzalez G, Camargo Jr CA, et al. Higher latitude and lower solar radiation influence on anaphylaxis in Chilean children. Pediatr Allergy Immunol: Off Publ Eur Soc Pediatr Allergy Immunol 2014;25:338-43.

[81] Hughes AM, Lucas RM, Ponsonby AL, Chapman C, Coulthard A, Dear K, et al The role of latitude, ultraviolet radiation exposure and vitamin D in childhood asthma and hayfever: an Australian multicenter study. Pediatr allergy Immunol: Off Publ Eur Soc Pediatr Allergy Immunol 2011;22: 327-33.

[82] Hypponen E, Sovio U, Wjst M, Patel S, Pekkanen J, Hartikainen AL, et al. Infant vitamin d supplementation and allergic conditions in adulthood: northern Finland birth cohort 1966. Ann N Y Acad Sci 2004;1037:84-95.

[83] Hypponen E, Berry DJ, Wjst M, Power C. Serum 25-hydroxyvitamin D and IgE - a significant but nonlinear relationship. Allergy 2009;64:613-20.

[84] Ito Y, Adachi Y, Yoshida K, Akasawa A. No association between serum vitamin D status and the prevalence of allergic diseases in Japanese children. Int Archiv allergy Immunol 2013;160:218-20.

[85] Jakso G. Studies on the anti-allergic effects of vitamin D2. Borgyogyaszati es Venerol Szle 1950;4:223-5.

[86] Janssens W, Bouillon R, Claes B, Carremans C, Lehouck A, Buysschaert I, et al. Vitamin D deficiency is highly prevalent in COPD and correlates with variants in the vitamin D-binding gene. Thorax 2010;65:215-20.

[87] Ji J, Hemminki K, Sundquist K, Sundquist J. Seasonal and regional variations of asthma and association with osteoporosis: possible role of vitamin D in asthma. J Asthma: Official J Assoc Care Asthma 2010;47:1045-8.

[88] Keet CA, McCormack MC, Peng RD, Matsui EC. Age- and atopy-dependent effects of vitamin D on wheeze and asthma. J Allergy Clin Immunol 2011;128:414-6. e5.

[89] Kelishadi R, Moeini R, Poursafa P, Farajian S, Yousefy H, OkhovatSouraki AA. Independent association between air pollutants and vitamin D deficiency in young children in Isfahan, Iran. Paediatr Int Child health 2014;34:50-5.

[90] Kemp AS, Ponsonby AL, Pezic A, Cochrane JA, Dwyer T, Jones G. The influence of sun exposure in childhood and adolescence on atopic disease at adolescence. Pediatr Allergy Immunol: Off Publ Eur Soc Pediatr Allergy Immunol 2013;24:493-500.

[92] Kerley CP, Elnazir BE, Faul F, Cormican L. Vitamin D as an adjunctive therapy in asthma. Part 1: a review of potential mechanisms. Pulm Pharmacol Ther 2015. http://dx.doi.org/10.1016/j.pupt.2015.02.004.

[93] Kolokotroni O, Papadopoulou A, Middleton N, Kouta C, Raftopoulos V, Nicolaidou P, et al. Vitamin D levels and status amongst asthmatic and nonasthmatic adolescents in Cyprus: a comparative cross-sectional study. BMC Public Health 2015;15:48.

[94] Korn S, Hubner M, Jung M, Blettner M, Buhl R. Severe and uncontrolled adult asthma is associated with vitamin D insufficiency and deficiency. Respir Res 2013;14:25.

[95] Krstic G. Asthma prevalence associated with geographical latitude and regional insolation in the United States of America and Australia. PloS One 2011;6:e18492.

[96] Krobtrakulchai W, Praikanahok J, Visitsunthorn N, Vichyanond P, Manonukul K, Pratumvinit B, et al. The effect of vitamin d status on pediatric asthma at a university hospital, Thailand. Allergy Asthma Immunol Res 2013;5:289-94.

[97] Kull I, Bergstrom A, Melen E, Lilja G, van Hage M, Pershagen G, et al. Early-life supplementation of vitamins A and D, in water-soluble form or in peanut oil and allergic diseases during childhood. J Allergy Clin Immunol 2006;118: 1299-304.

[98] Kull I, Hallner E, Lilja G, Ohman-Johansson AC, Oman H, Wickman M. Peanut oil in vitamin A and D preparations: reactions to skin test and manifestation of symptoms. Pediatr Allergy Immunol: Off Publ Eur Soc Pediatr Allergy Immunol 1999;10:21-6.

[99] Lambert AA, Kirk GD, Astemborski J, Neptune ER, Mehta SH, Wise RA, et al. A cross sectional analysis of the role of the antimicrobial peptide cathelicidin in lung function impairment within the ALIVE cohort. PloS One 2014;9: e95099.

[100] Lan N, Luo G, Yang X, Cheng Y, Zhang Y, Wang X, et al. 25-hydroxyvitamin D3-deficiency enhances oxidative stress and corticosteroid resistance in severe asthma exacerbation. PloS One 2014:9:e111599.

[101] Lange NE, Sparrow D, Vokonas P, Litonjua AA. Vitamin D deficiency, smoking, and lung function in the Normative Aging Study. Am J Respir Crit Care Med 2012;186:616-21.

[102] Larose TL, Langhammer A, Chen Y, Camargo Jr CA, Romundstad P, Mai XM. Serum 25-hydroxyvitamin D levels and lung function in adults with asthma: the HUNT Study. Eur Respir J 2014. pii: erj00697-2014.

[103] Lee J, Zhao H, Fenta Y, Kita H, Kumar R, Juhn YJ. Serum 25-hydroxyvitamin D is associated with enhanced pneumococcal antibody levels in individuals with asthma. Allergy Asthma Proc: Off J Regional State Allergy Soc 2011;32: 445-52.

[104] Lewis E, Fernandez C, Nella A, Hopp R, Gallagher JC, Casale TB. Relationship of 25-hydroxyvitamin D and asthma control in children. Ann Allergy Asthma Immunol: Off Publ Am Coll Allergy Asthma Immunol 2012;108: $281-2$.

[105] Li F, Peng M, Jiang L, Sun Q, Zhang K, Lian F, et al. Vitamin D deficiency is associated with decreased lung function in Chinese adults with asthma. Respiration 2011;81:469-75.

[106] Litonjua AA. Childhood asthma may be a consequence of vitamin D deficiency. Curr Opin Allergy Clin Immunol 2009;9:202-7.

[107] Litonjua AA, Weiss ST. Is vitamin D deficiency to blame for the asthma epidemic? J Allergy Clin Immunol 2007;120:1031-5.

[108] Liu MC, Xiao HQ Brown AJ, Ritter CS, Schroeder J. Association of vitamin D and antimicrobial peptide production during late-phase allergic responses in the lung. Clin Exp Allergy: J Br Soc Allergy Clin Immunol 2012;42:383-91.

[109] Maalmi H, Berraies A, Tangour E, Ammar J, Abid H, Hamzaoui K, et al. The impact of vitamin D deficiency on immune $T$ cells in asthmatic children: a case-control study. J Asthma Allergy 2012;5:11-9.

[110] Mai XM, Langhammer A, Chen Y, Camargo Jr CA. Cod liver oil intake and incidence of asthma in Norwegian adults-the HUNT study. Thorax 2013;68: 25-30.

[111] Majak P, Rychlik B, Stelmach I. The effect of oral steroids with and without vitamin D3 on early efficacy of immunotherapy in asthmatic children. Clin Exp Allergy: J Br Soc Allergy Clin Immunol 2009;39:1830-41.

[112] Majak P, Olszowiec-Chlebna M, Smejda K, Stelmach I. Vitamin D supplementation in children may prevent asthma exacerbation triggered by acute respiratory infection. J Allergy Clin Immunol 2011;127:1294-6.

[113] Majak P, Jerzynska J, Smejda K, Stelmach I, Timler D, Stelmach W. Correlation of vitamin D with Foxp3 induction and steroid-sparing effect of immunotherapy in asthmatic children. Ann Allergy Asthma Immunol: off Publ Am Coll Allergy Asthma Immunol 2012;109:329-35.

[114] Mallol J, Sole D, Baeza-Bacab M, Aguirre-Camposano V, Soto-Quiros M, Baena-Cagnani C. Regional variation in asthma symptom prevalence in Latin American children. J Asthma: Off J Assoc Care Asthma 2010;47:644-50.

[115] Masoli M, Fabian D, Holt S, Beasley R. The global burden of asthma: executive summary of the GINA Dissemination Committee report. Allergy 2004;59: 469-78.

[116] Matsuoka LY, Ide L, Wortsman J, MacLaughlin JA, Holick MF. Sunscreens suppress cutaneous vitamin D3 synthesis. J Clin Endocrinol Metab 1987;64: 1165-8.

[117] McGlade JP, Gorman S, Zosky GR, Larcombe AN, Sly PD, Finlay-Jones JJ, et al Suppression of the asthmatic phenotype by ultraviolet B-induced, antigenspecific regulatory cells. Clin Exp Allergy: J Br Soc Allergy Clin Immunol 2007;37:1267-76.

[118] McGlade JP, Strickland DH, Lambert MJ, Gorman S, Thomas JA, Judge MA, et al. UV inhibits allergic airways disease in mice by reducing effector CD4 T cells. Clin Exp Allergy: J Br Soc Allergy Clin Immunol 2010;40:772-85.

[119] Meng YY, Babey SH, Hastert TA, Brown ER. California's racial and ethnic minorities more adversely affected by asthma (UCLA Center for Health Policy Research) Policy Brief 2007:1-7.

[120] Menon J, Maranda L, Nwosu BU. Serum 25-hydroxyvitamin D levels do not correlate with asthma severity in a case-controlled study of children and adolescents. J Pediatr Endocrinol Metab: JPEM 2012;25:673-9.

[121] Mirzakhani H, Al-Garawi A, Weiss ST, Litonjua AA. Vitamin D and the development of allergic disease: how important is it? Clin Exp Allergy: J Br Soc Allergy Clin Immunol 2015;45:114-25.

[122] Montero-Arias F, Sedo-Mejia G, Ramos-Esquivel A. Vitamin d insufficiency and asthma severity in adults from costa rica. Allergy Asthma Immunol Res $2013 ; 5: 283-8$. 
[123] Mulligan JK, Nagel W, O'Connell BP, Wentzel J, Atkinson C, Schlosser RJ. Cigarette smoke exposure is associated with vitamin D3 deficiencies in patients with chronic rhinosinusitis. J Allergy Clin Immunol 2014;134: 342-9.

[124] Munns CF, Simm PJ, Rodda CP, Garnett SP, Zacharin MR, Ward LM, et al. Incidence of vitamin D deficiency rickets among Australian children: an Australian Paediatric Surveillance Unit study. Med J Aust 2012;196:466-8.

[125] Nageswari AD, Rajanandh MG, Priyanka RK, Rajasekhar P. Effect of vitamin D3 on mild to moderate persistent asthmatic patients: a randomized controlled pilot study. Perspect Clin Res 2014;5:167-71.

[126] Nanzer AM, Chambers ES, Ryanna K, Freeman AT, Colligan G, Richards DF, et al. The effects of calcitriol treatment in glucocorticoid-resistant asthma, J Allergy Clin Immunol 2014;133:1755-7. e4.

[127] Ng TP, Niti M, Yap KB, Tan WC. Dietary and supplemental antioxidant and anti-inflammatory nutrient intakes and pulmonary function. Public Health Nutr 2014;17:2081-6.

[128] Niruban SJ, Alagiakrishnan K, Beach J, Senthilselvan A. Association of vitamin D with respiratory outcomes in Canadian children. Eur J Clin Nutr 2014;68: 1334-40.

[129] Nja F, Nystad W, Lodrup Carlsen KC, Hetlevik O, Carlsen KH. Effects of early intake of fruit or vegetables in relation to later asthma and allergic sensitization in school-age children. Acta Paediatr 2005;94:147-54 [Oslo, Norway : 1992].

[130] Norizoe C, Akiyama N, Segawa T, Tachimoto H, Mezawa H, Ida H, et al. Increased food allergy and vitamin D: randomized, double-blind, placebocontrolled trial. Pediatr Int: Off J Jpn Pediatr Soc 2014;56:6-12.

[131] Oktaria V, Dharmage SC, Burgess JA, Simpson JA, Morrison S, Giles GG, et al. Association between latitude and allergic diseases: a longitudinal study from childhood to middle-age. Ann Allergy Asthma Immunol: Off Publ Am Coll Allergy Asthma Immunol 2013;110:80-5. e1.

[132] Oren E, Banerji A, Camargo Jr CA. Vitamin D and atopic disorders in an obese population screened for vitamin D deficiency. J Allergy Clin Immunol 2008;121:533-4.

[133] Ozaydin E, Butun MF, Cakir BC, Kose G. The association between vitamin d status and recurrent wheezing. Indian J Pediatr 2013;80:907-10.

[134] Pojsupap S, Iliriani K, Sampaio TZ, O'Hearn K, Kovesi T, Menon K, et al. Efficacy of high-dose vitamin D in pediatric asthma: a systematic review and meta-analysis. J Asthma: Off J Assoc Care Asthma 2014:1-9.

[135] Rajabbik MH, Lotfi T, Alkhaled L, Fares M, El-Hajj Fuleihan G, Mroueh S, et al. Association between low vitamin D levels and the diagnosis of asthma in children: a systematic review of cohort studies. Allergy Asthma Clin Immunol: Off J Can Soc Allergy Clin Immunol 2014;10:31.

[136] Rappaport BZ, Reed CI, Hathaway ML, Struck HC. The treatment of hay fever and asthma with viosterol of high potency. J Allergy 1934;5:541-53.

[137] Rappaport BZ, Reed CI. Viosterol of high potency in seasonal hay fever and related conditions. JAMA 1933;101(2):105-9.

[138] Reid D, Toole BJ, Knox S, Talwar D, Harten J, O'Reilly DS, et al. The relation between acute changes in the systemic inflammatory response and plasma 25-hydroxyvitamin D concentrations after elective knee arthroplasty. Am J Clin Nutr 2011;93:1006-11.

[139] Ross AC, Manson JE, Abrams SA, Aloia JF, Brannon PM, Clinton SK, et al. The 2011 report on dietary reference intakes for calcium and vitamin D from the Institute of Medicine: what clinicians need to know. J Clin Endocrinol Metab 2011;96:53-8.

[140] Rothers J, Wright AL, Stern DA, Halonen M, Camargo Jr CA. Cord blood 25hydroxyvitamin D levels are associated with aeroallergen sensitization in children from Tucson, Arizona. J Allergy Clin Immunol 2011;128:1093-9. e15.

[141] Ryoo E, Kumar R, Kita H, Juhn YJ. Serum 25-hydroxyvitamin D concentrations and waning pneumococcal antibody titers among individuals with atopy. Allergy Asthma Proc: Off J Regional State Allergy Soc 2013;34:370-7.

[142] Salas NM, Luo L, Harkins MS. Vitamin D deficiency and adult asthma exacerbations. J Asthma: Off J Assoc Care Asthma 2014;51:950-5.

[143] Samrah S, Khatib I, Omari M, Khassawneh B, Momany S, Daoud A, et al. Vitamin D deficiency and level of asthma control in women from North of Jordan: a case-control study. J Asthma: Off J Assoc Care Asthma 2014;51: 832-8.

[144] Sanders KM, Stuart AL, Williamson EJ, Simpson JA, Kotowicz MA, Young D, et al. Annual high-dose oral vitamin D and falls and fractures in older women: a randomized controlled trial. JAMA 2010;303:1815-22.

[145] Scragg R, Holdaway I, Singh V, Metcalf P, Baker J, Dryson E. Serum 25hydroxyvitamin D3 is related to physical activity and ethnicity but not obesity in a multicultural workforce. Aust N Z J Med 1995;25:218-23.

[146] Searing DA, Zhang Y, Murphy JR, Hauk PJ, Goleva E, Leung DY. Decreased serum vitamin D levels in children with asthma are associated with increased corticosteroid use. J Allergy Clin Immunol 2010;125:995-1000.

[147] Shaheen SO, Jameson KA, Robinson SM, Boucher BJ, Syddall HE, Sayer AA, et al. Relationship of vitamin D status to adult lung function and COPD. Thorax 2011;66:692-8.

[148] Sharief S, Jariwala S, Kumar J, Muntner P, Melamed ML. Vitamin D levels and food and environmental allergies in the United States: results from the National Health and Nutrition Examination Survey 2005-2006. J Allergy Clin Immunol 2011;127:1195-202.

[149] Somashekar AR, Prithvi AB, Gowda MN. Vitamin D levels in children with bronchial asthma. J Clin Diagn Res: JCDR 2014;8:c04-7.
[150] Song WJ, Kim SH, Lim S, Park YJ, Kim MH, Lee SM, et al. Association between obesity and asthma in the elderly population: potential roles of abdominal subcutaneous adiposity and sarcopenia. Ann Allergy Asthma Immunol: Off Publ Am Coll Allergy Asthma Immunol 2012;109:243-8.

[151] Staples JA, Ponsonby AL, Lim LL, McMichael AJ. Ecologic analysis of some immune-related disorders, including type 1 diabetes, in Australia: latitude, regional ultraviolet radiation, and disease prevalence. Environ Health Perspect 2003; 111:518-23.

[152] Stenberg Hammar K, Hedlin G, Konradsen JR, Nordlund B, Kull I, Giske CG, et al. Subnormal levels of vitamin D are associated with acute wheeze in young children. Acta Paediatr 2014;103:856-61 [Oslo, Norway: 1992].

[153] Supervia A, Nogues X, Enjuanes A, Vila J, Mellibovsky L, Serrano S, et al. Effect of smoking and smoking cessation on bone mass, bone remodeling, vitamin D, PTH and sex hormones. J Musculoskelet Neuronal Interact 2006;6: 234-41.

[154] Sutherland ER, Goleva E, Jackson LP, Stevens AD, Leung DY. Vitamin D levels, lung function, and steroid response in adult asthma. Am J Respir Crit Care Med 2010;181:699-704.

[155] Termorshuizen F, Wijga A, Gerritsen J, Neijens HJ, van Loveren H. Exposure to solar ultraviolet radiation and respiratory tract symptoms in 1-year-old children. Photodermatol Photoimmunol Photomed 2004;20:270-1.

[156] Thuesen BH, Skaaby T, Husemoen LL, Fenger M, Jorgensen T, Linneberg A. The association of serum 25-OH vitamin D with atopy, asthma, and lung function in a prospective study of Danish adults. Clin Exp Allergy: J Br Soc Allergy Clin Immunol 2015;45:265-72.

[157] Tolppanen AM, Sayers A, Granell R, Fraser WD, Henderson J, Lawlor DA. Prospective association of 25-hydroxyvitamin $\mathrm{d} 3$ and $\mathrm{d} 2$ with childhood lung function, asthma, wheezing, and flexural dermatitis. Epidemiology 2013;24:310-9.

[158] Tolppanen AM, Williams D, Henderson J, Lawlor DA. Serum 25-hydroxyvitamin D and ionised calcium in relation to lung function and allergen skin tests. Eur J Clin Nutr 2011;65:493-500.

[159] Tripkovic L, Lambert H, Hart K, Smith CP, Bucca G, Penson S, et al. Comparison of vitamin D2 and vitamin D3 supplementation in raising serum 25hydroxyvitamin D status: a systematic review and meta-analysis. Am J Clin Nutr 2012;95:1357-64.

[160] Urashima M, Segawa T, Okazaki M, Kurihara M, Wada Y, Ida H. Randomized trial of vitamin D supplementation to prevent seasonal influenza A in schoolchildren. Am J Clin Nutr 2010;91:1255-60.

[161] Utz G, Hauck AM. Oral application of calcium and vitamin D2 in allergic bronchial asthma (author's transl). MMW Munch Med Wochenschr 1976;118:1395-8.

[162] Uysalol M, Uysalol EP, Yilmaz Y, Parlakgul G, Ozden TA, Ertem HV, et al. Serum level of vitamin D and trace elements in children with recurrent wheezing: a cross-sectional study. BMC Pediatr. 2014 Oct 16;14:270.

[163] van den Heuvel EG, van Schoor N, de Jongh RT, Visser M, Lips P. Crosssectional study on different characteristics of physical activity as determinants of vitamin D status; inadequate in half of the population. Eur J Clin Nutr 2013;67:360-5.

[164] van Oeffelen AA, Bekkers MB, Smit HA, Kerkhof M, Koppelman GH, Haveman-Nies A, et al. Serum micronutrient concentrations and childhood asthma: the PIAMA birth cohort study. Pediatr Allergy Immunol: Off Publ Eur Soc Pediatr Allergy Immunol 2011;22:784-93.

[165] van Schoor NM, de Jongh RT, Daniels JM, Heymans MW, Deeg DJ, Lips P. Peak expiratory flow rate shows a gender-specific association with vitamin D deficiency. J Clin Endocrinol Metab 2012;97:2164-71.

[166] Varney VA, Evans J, Bansal AS. Successful treatment of reactive airways dysfunction syndrome by high-dose vitamin D. J Asthma Allergy 2011;4: 87-91.

[167] Vieth R. Why the minimum desirable serum 25-hydroxyvitamin D level should be $75 \mathrm{nmol} / \mathrm{L}(30 \mathrm{ng} / \mathrm{ml}$ ). Best Pract Res Clin Endocrinol Metab 2011;25:681-91.

[168] Waldron JL, Ashby HL, Cornes MP, Bechervaise J, Razavi C, Thomas OL, et al. Vitamin D: a negative acute phase reactant. J Clin Pathol 2013;66: $620-2$.

[169] Wawro N, Heinrich J, Thiering E, Kratzsch J, Schaaf B, Hoffmann B, et al. Serum 25(OH)D concentrations and atopic diseases at age 10: results from the GINIplus and LISAplus birth cohort studies. BMC Pediatr 2014:14:286.

[170] Weiland SK, Husing A, Strachan DP, Rzehak P. Pearce N. Climate and the prevalence of symptoms of asthma, allergic rhinitis, and atopic eczema in children. Occup Environ Med 2004;61:609-15.

[171] Weiss ST, Litonjua AA. Maternal diet vs lack of exposure to sunlight as the cause of the epidemic of asthma, allergies and other autoimmune diseases. Thorax 2007;62:746-8.

[172] Welliver Sr RC. Temperature, humidity, and ultraviolet B radiation predict community respiratory syncytial virus activity. Pediatr Infect Dis J 2007;26: S29-35.

[173] Wittke A, Chang A, Froicu M, Harandi OF, Weaver V, August A, et al. Vitamin D receptor expression by the lung micro-environment is required for maximal induction of lung inflammation. Archiv Biochem Biophys 2007;460: 306-13.

[174] Wittke A, Weaver V, Mahon BD, August A, Cantorna MT. Vitamin D receptordeficient mice fail to develop experimental allergic asthma. J Immunol 2004;173:3432-6 (Baltimore, Md: 1950).

[175] Wjst M. The triple T allergy hypothesis. Clin Dev Immunol 2004;11:175. 
C.P. Kerley et al. / Pulmonary Pharmacology \& Therapeutics 32 (2015) 75-92

[176] Wjst M. Another explanation for the low allergy rate in the rural Alpine foothills. Clin Mol Allergy: CMA 2005;3:7.

[177] Wjst M. Introduction of oral vitamin D supplementation and the rise of the allergy pandemic. Allergy Asthma Clin Immunol off J Can Soc Allergy Clin Immunol 2009;5:8.

[178] Wjst M. Is vitamin D supplementation responsible for the allergy pandemic? Curr Opin Allergy Clin Immunol 2012;12:257-62.

[179] Wjst M, Altmuller J, Braig C, Bahnweg M, Andre E. A genome-wide linkage scan for 25-OH-D(3) and 1,25-(OH)2-D3 serum levels in asthma families. J Steroid Biochem Mol Biol 2007;103:799-802.

[180] Wjst M, Dold S. Genes, factor X, and allergens: what causes allergic diseases? Allergy 1999;54:757-9.

[181] Wjst M, Hypponen E. Vitamin D serum levels and allergic rhinitis. Allergy 2007;62:1085-6.

[182] Wu AC, Tantisira K, Li L, Fuhlbrigge AL, Weiss ST, Litonjua A. Effect of vitamin $\mathrm{D}$ and inhaled corticosteroid treatment on lung function in children. Am J Respir Crit Care Med 2012;186:508-13.
[183] Yadav M, Mittal K. Effect of vitamin D supplementation on moderate to severe bronchial asthma. Indian J Pediatr 2014;81:650-4.

[184] Yao TC, Tu YL, Chang SW, Tsai HJ, Gu PW, Ning HC, et al. Serum 25hydroxyvitamin D levels in relation to lung function and exhaled nitric oxide in children. J Pediatr 2014;165:1098-103. e1.

[185] Yao TC, Tu YL, Chang SW, Tsai HJ, Gu PW, Ning HC, et al. Suboptimal vitamin D status in a population-based study of Asian children: prevalence and relation to allergic diseases and atopy. PloS One 2014;9:e99105.

[186] Yusuf S, Piedimonte G, Auais A, Demmler G, Krishnan S, Van Caeseele P, et al. The relationship of meteorological conditions to the epidemic activity of respiratory syncytial virus. Epidemiol Infect 2007;135:1077-90.

[187] Zanolin ME, Pattaro C, Corsico A, Bugiani M, Carrozzi L, Casali L et al. The role of climate on the geographic variability of asthma, allergic rhinitis and respiratory symptoms: results from the Italian study of asthma in young adults. Allergy 2004;59:306-14.

[188] Zaragoza Buxo J, Perez L, Bredy R. Relation between serum vitamin D level and asthma. Boletin la Asoc Medica P. R 2012;104:12-6. 